\title{
The applicability of spectroscopy methods for estimating potentially toxic elements in soils: state-of-the-art and future trends
}

\author{
Nawar, S. ${ }^{a^{*}}$, Cipullo, S ${ }^{\mathrm{b}}$, Douglas, R.K. ${ }^{\mathrm{b}}$, Frederic Coulon, F ${ }^{\mathrm{b}}$, Mouazen, A.M. ${ }^{\mathrm{a}}$

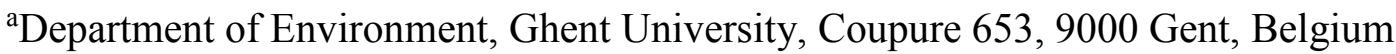 \\ ${ }^{\mathrm{b}}$ Cranfield University, School of Water, Energy and Environment, Cranfield, MK430AL, UK \\ *E-mail of corresponding author: said.nawar@ugent.be; abdul.mouazen@ugent.be
}

\begin{abstract}
Potentially toxic elements (PTEs) in soils pose severe threats to the environment and human health. It is therefore imperative to have access to simple, rapid, portable and accurate methods for their detection in soils. In this regards, the review introduces recent progresses made in the development and applications of spectroscopic methods for in-situ semi-quantitative and quantitative detection of PTEs in soil and critically compares them to standard analytical methods. The advantages and limitations of these methods are discussed together with recent advances in chemometrics and data mining techniques allowing to extract useful information based on spectral data. Furthermore, the factors influencing soil spectra and data analysis are discussed and recommendations on how to reduce or eliminate their influences are provided. Future research and development needs for spectroscopy techniques are emphasized, and an analytical framework based on technology integration and data fusion is proposed to improve the measurement accuracy of PTEs in soil.
\end{abstract}

Keywords: Spectroscopy, analytical techniques, contaminated soil, potentially toxic elements. 


\section{Contents}

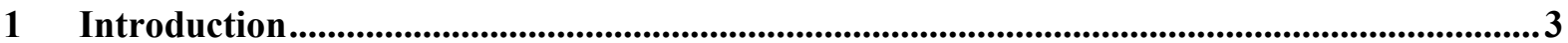

2 Reasons for using the term "PTE" instead of heavy metals......................................................6

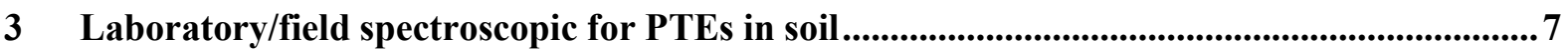

3.1 X-ray fluorescence spectroscopy (XRFS)...............................................................

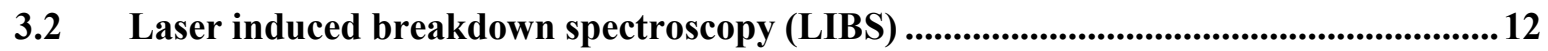

3.3 Visible and near-infrared spectroscopy (Vis-NIRS) ....................................................17

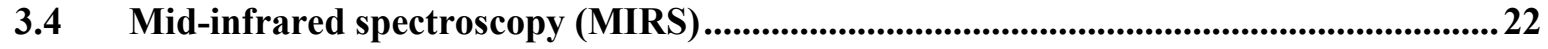

$4 \quad$ Data and model fusion methods...............................................................................................24

5 Selection of optimal optical technique for PTE analysis ............................................................2 27

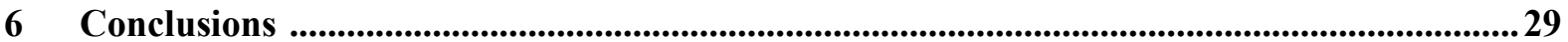

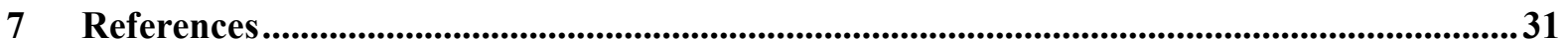




\section{Introduction}

Soil contamination by PTEs is a global concern as they can cause serious health problems to human and ecosystems $(1,2,3)$. While it is usually difficult to list or specify all PTEs found in soil as there are over 40 chemical elements (4), a list of 21 elements is commonly used for PTEs. The list includes antimony $(\mathrm{Sb})$, arsenic (As), barium $(\mathrm{Ba})$, cadmium $(\mathrm{Cd})$, chromium $(\mathrm{Cr})$, cobalt $(\mathrm{Co})$, copper $(\mathrm{Cu})$, gold $(\mathrm{Au})$, lead $(\mathrm{Pb})$, manganese $(\mathrm{Mn})$, mercury $(\mathrm{Hg})$, molybdenum (Mo), nickel (Ni), selenium (Se), silver (Ag), thallium (Tl), tin ( $\mathrm{Sn})$, tungsten (W), uranium (U), vanadium (V) and zinc (Zn) (5). Among these elements, 8 PTEs, including $\mathrm{Pb}, \mathrm{Cr}, \mathrm{As}, \mathrm{Zn}, \mathrm{Cd}, \mathrm{Cu}, \mathrm{Hg}$, and $\mathrm{Ni}$ are considered as the most commonly elements found at contaminated sites (6).

Metal ions are non-biodegradable and can accumulate in soft tissues, hence, they are considered as posing a significant risk to health, and cause of many toxic and physiological diseases to both humans and livestock $(7,8)$. This is the case particularly for, but not limited to, $\mathrm{As}, \mathrm{Cd}, \mathrm{Hg}$, and $\mathrm{Pb}$, even they are present in relatively low concentrations (9-11). Thus, there is a need to gain a better understanding and assessment of the distribution and potential hazards posed by the presence of PTEs in soils, in order to ensure food safety and environmental and public health protection.

Various analytical techniques have been developed for the detection of PTEs, including electrochemical $(12,13)$, voltammetry (14), and optical (15) methods. Laboratory optical methods include inductively coupled plasma atomic emission spectroscopy (ICP-AES) (also referred to as inductively coupled plasma optical emission spectroscopy (ICP-OES)), inductively coupled plasma mass spectroscopy (ICP-MS)), atomic fluorescence spectrometry (AFS), X-ray fluorescence spectrometry (XRFS), laser-induced breakdown spectroscopy 
(LIBS), neutron activation analysis (NAA), and atomic absorption spectrophotometry (AAS). These laboratory methods are sufficient for quantitative estimation with good detection limits, and have been widely used to detect different PTEs in soil samples, with high sensitivity, selectivity and accuracy $(14,15)$. However, all these techniques require relatively expensive instrumentation, the measurement procedure takes as relatively and needed long time and specialized personnel are necessary to carry out the measurements correctly (14).

Given the limitations and cost of the laboratory methods listed above, there have been tremendous efforts made to provide accurate rapid measurement techniques for in-situ measurement (16). Cutting-edge technologies such as portable and powerful computers, software packages, fibre optics and spatial modelling have contributed significantly to assessment of the presence, distribution and potential hazards posed by the presence of PTEs in soils. Contextually, proximal soil sensing offers high sampling resolution combined with cheaper measurements procedures $(16,17)$. Proximal soil sensing refers to the use of all field methods to obtain signals from the soil when the probe is in contact with or close to (within 2 m) the soil (18). It includes electromagnetic induction (EMI), gamma radiometry (GR), and ground-penetrating radar (GPR), electrochemical sensors, and field spectroscopic methods such as visible and near-infrared spectroscopy (Vis-NIRS), mid-infrared spectroscopy (MIRS) and portable X-ray fluorescence spectroscopy (PXRFS) spectroscopy and portable LIBS. The suitability of these techniques for laboratory and/or the field measurement has been extensively verified $(16,19)$.

Since the 1990s, there has been a tremendous increase in the use of portable Vis-NIRS spectrophotometers for on-site determination of various analytes (17). These portable instruments are non-destructive, easy to use and offer rapid measurement as there is no sample preparation needed. These characteristics are all essential for cost-effective in situ measurement $(16,20)$. Likewise, MIRS has been successfully used for predicting soil 
parameters including PTEs concentrations (21), despite the complex nature of soil matrix and the sensitivity of MIRS to moisture content that can impact the accuracy of measurement. PXRFS has advantages over the traditional methods, in that it offers in situ, rapid detection and accurate quantification of a wide range of elements present in the soil, with little, or no, need for sample preparation (19).

In recent years, there has been a remarkable increase in the development of rapid sensorbased in situ applications of proximal soil sensing technologies to detect and monitor PTEs contaminants in soils. Among them, PXRFS has been extensively adopted (16, 22). In the last few years, portable LIBS has been developed to measure PTEs in situ (23-25). Others used vibrational spectroscopy methods including Vis-NIRS and MIRS to monitor and measure PTEs in soil also has been used $(3,16,26,27)$. All studies conducted to date agree that fieldbased, in situ, spectroscopic techniques offer rapid, non-destructive and cost-effective methods to determine on-site presence, level and spatial distribution of PTEs prior to undertaking laboratory-based chemical estimation that might be more accurate but would be much more expensive and time-consuming. Furthermore, on-site spectroscopic techniques can provide real-time monitoring and, consequently, helpful information for preliminary site assessment, and guide further sampling for a comprehensive risk assessment of contaminated sites. Nevertheless, spectral data analysis requires careful examination to avoid misleading interpretations. Multi-sensor and data fusion approaches have attracted much attention for estimating soil properties (28-30); however, this field is still in its infancy as far as accurate PTE detection and mapping in soils is concerned.

The aim of this paper is to provide a critical review of the potential of those spectroscopy techniques currently available for the analysis of PTEs in soils, with a particular emphasis on portable XRFS, LIBS, Vis-NIRS and MIRS methods for on-site measurement. In addition, a 
discussion on the main factors or variables affecting the implementation of these methods is provided along with suggestions for improving performance and accuracy for in situ measurement.

\section{Reasons for using the term "PTE" instead of heavy metals}

The term "heavy metal" has never been precisely defined and has become the subject of a broad discussion (31-34), implying different things to different people (35). A wide variety of definitions can be found in the Web of Science and Google Search, including elements that form soaps upon reaction with fatty acids, have an atomic weight greater than $\mathrm{Na}$ (22.9), e.g., $\mathrm{Al}, \mathrm{Co}$, and $\mathrm{Pb}$ elements with a specific gravity of approximately 5.0 or higher, e.g., $\mathrm{Pb}, \mathrm{Ag}$, $\mathrm{Cr}, \mathrm{Co}, \mathrm{Cu}, \mathrm{Ni}$, and $\mathrm{Hg}$; and elements that can be precipitated by hydrogen sulphide in acid solution, e.g., $\mathrm{Ag}, \mathrm{Au}, \mathrm{Pb}, \mathrm{Hg}, \mathrm{Bi}$, and $\mathrm{Cu}(33)$.

Furthermore the term "Heavy metal" has never been defined by any authoritative body, such as the International Union of Pure and Applied Chemistry (IUPAC), nor is there any widely agreed criterion-based definition of a heavy metal, indeed the term "heavy metal" is considered imprecise at best, meaningless at worst and its use is strongly discouraged (3637). It has been suggested by (34) that term "heavy metals" be replaced with, e.g., "potentially toxic element(s)/metal(s)" or "trace element(s)/metal(s)", according to the context. Because not all trace metals are toxic, the term which has gained acceptance is "potentially toxic elements" (PTEs).

Indeed, the term PTEs is more inclusive and appropriate than "heavy metal" (33) and will be used in this paper. While laboratory atomic spectroscopic methods are frequently the choice for the analyses of PTEs (38-40), the focus of this review is on portable optical spectroscopy methods: XRFS and LIBS (both atomic spectroscopy), and Vis-NIRS, and MIRS (both molecular spectroscopy). The discussion will be steered towards the potential implementation 
of these portable spectroscopy techniques for in situ measurement, highlighting the advantages and disadvantages of each technique. A new approach for multi-spectroscopy sensor data fusion is suggested, as the optimal solution for in situ detection and mapping of PTEs.

\section{Laboratory/field spectroscopy methods for analysis of PTEs in soil}

The laboratory methods for the analyses of PTEs listed above, are both expensive and time consuming, so the number of samples analysed will invariably be limited, which prevents the collection of a large number of samples from across the entire site to assess and accurately map field contamination. Such methods do not usually fulfil the requirement for rapid measurement and risk assessment of soil contamination. It is necessary to be able to detect and measure elements posing a danger to health quickly, cost-effectively and in situ. There is a need for portable, economical and rapid sensing technologies, and this can be achieved by spectroscopy techniques. This section focuses on portable spectroscopy methods that can be used in both field conditions and the laboratory; PXRFS, LIBS, Vis-NIRS and MIRS.

\subsection{X-ray fluorescence spectroscopy (XRFS)}

Several studies and practical applications have demonstrated that XRFS is a suitable tool for industrial and environmental applications. XRFS is a well-known laboratory technique (41), which has been widely used since the 1950s for elemental analysis (19). The energy as well as intensity associated with characteristic-fluoresced radiation from the elements in a given sample are used to recognize and determine their presence and concentrations (42). When a single atom is excited by an external energy source, it emits photons of a characteristic energy or wavelength. The elements present in a given sample may be identified and quantified by counting the number of photons of each energy emitted (43). 
Fluorescence is a form of luminescence that occurs when the emitted light has a longer wavelength (lower energy) than the absorbed radiation (19). Elemental identification in a given sample is based on the relationship between emission wavelength and atomic number, while the elemental concentration can be estimated from the characteristic line intensities (number of photons of each wavelength) $(44,45)$. This has proved to be a highly sensitive technique for PTEs analysis (46-48) with accurate multi-element analysis of rock samples (47), and soils matrices (49-53). With recent technological improvements, PXRFS has now become available, for rapid and cost-effective on-site measurement of soil contaminants (16, $54)$.

Using portable analytical methods, such as PXRFS, for assessing contamination has many advantages, including; increased efficiency, cost-effectiveness, convenience and ease of use, real-time information for on-site decision-making, minimal sample preparation required, multi-element measurement capability, potential for relatively low detection limits and better representation of contaminant distribution. (55-58). Such non-destructive testing also has no negative impact on the environment, PXRFS has been accepted by the environmental community as valuable technique for analysing environmental samples with several advantages over other optical analytical methods such as AAS, ICP-AES and ICP-MS (59). PXRFS has been used for rapid field screening of As contaminants with a strong correlation between the obtained results, and those from of AAS laboratory analysis (60). In addition, PXRFS has been successfully used for both in situ and ex situ (laboratory) analysis for the quantification of $\mathrm{Pb}, \mathrm{Zn}, \mathrm{As}, \mathrm{Cd}$, and $\mathrm{Cu}$ in paddy soils near a multi-contaminated mining area (61). The obtained results for both in situ and ex situ sampling were close to those obtained by Korean standard laboratory tests (coefficient of determination: $\mathrm{R}^{2}$ close to 1.0 ) for $\mathrm{Pb}$ and $\mathrm{Zn}$ (61). Radu and Diamond (62) compared two PXRFS instruments with AAS analysis of aqua regia digested soil samples for estimating $\mathrm{As}, \mathrm{Zn}, \mathrm{Pb}$, and $\mathrm{Cu}$ in old mining 
areas of Ireland. The authors reported excellent to very strong correlations ( $\mathrm{R}^{2}$ of 0.99 for As, 0.99 for $\mathrm{Pb}, 0.96$ for $\mathrm{Cu}$, and 0.84 for $\mathrm{Zn}$ ) between the two methods. They recommended PXRFS due to its speed because there was no need for sample digestion. Kilbride et al. (63) compared ICP-OES assessment of aqua regia extraction method with two types of field PXRFS systems (X-ray tube and dual isotope) for determination of $\mathrm{As}, \mathrm{Cd}, \mathrm{Cu}, \mathrm{Fe}, \mathrm{Mn}, \mathrm{Pb}$ and $\mathrm{Zn}$ in selected industrial areas of the UK. These Authors reported a high correlation between X-ray tube measurements and ICP-OES results for $\mathrm{Fe}$ and $\mathrm{Pb}$ better than the dual isotope, whereas higher correlations for $\mathrm{Cd}, \mathrm{Cu}, \mathrm{Mn}$, and $\mathrm{Zn}$ were obtained with the dual isotope instrument measurements.

There are general limitations faced by users of PXRFS such as the need for official approval for field measurement, the need for a field expertise (19) and the health risks associated with X-ray radiation. The complex relationship between the intensity of the characteristic X-ray emission of an element and its concentration within a material is a limitation on the measurement which requires a correction to be applied to the measurements (64). However, internal calibration by the manufacture such as fundamental parameter (FP) overcomes this limitation and PXRFS produces robust data that accurately reflects material composition (45). Interference caused by physical-matrix effects (e.g., particle size, and surface conditions), chemical-matrix effects causing elemental interference (e.g., As and $\mathrm{Pb}$ ), and moisture content $(>20 \%)$ should be considered and minimized (19). Variation in soil samples is a challenge for PXRFS measurement, inhomogeneity resulting from coarse textures, veins, phenocrysts, localized mineralization and irregularities of the surface reduce the accuracy of measurement $(65,66)$. Similarly, spectral interference between elements such $\mathrm{As}$ and $\mathrm{Pb}$ associated with a shared spectral peak reduces the estimation accuracy $(67,68)$. Moisture content reduces the PXRFS measurement and needs to be corrected to dry conditions. For example, Weindorf et al. (69) compared the accuracy of PXRF measurement for soils 
samples under four different moisture conditions: dry, moist, frozen in situ, refrozen in lab. They reported significantly improved results using linear regression equations (higher $\mathrm{R}^{2}$, lower RMSE, and slopes closer to 1) by applying a moisture correction factor of elemental data to dry.

In order to optimise the PXRF measurement and output, Binstock et al. (70) developed a new protocol for measurements. This consisted of drying and sieving collected samples to $<50 \mu \mathrm{m}$ particle sizes. Results for $\mathrm{Pb}$ showed no statistical difference between paired ICP-AES and PXRFS. Figueroa-Cisterna et al. (71) used a combination of ex situ PXRFS with different multivariate statistical techniques (e.g., cluster analysis (HCA), principle component analysis (PCA), factor discriminant analysis (FA), and linear discriminant analysis (LDA)) to develop calibration models for in situ measurement of $\mathrm{K}, \mathrm{Ca}, \mathrm{Cu}, \mathrm{Fe}, \mathrm{Mn}, \mathrm{Pb}, \mathrm{Ti}, \mathrm{Zn}, \mathrm{Rb}$, and $\mathrm{Sr}$ in Boris Angelo mining area of Central Chile. They concluded that the proposed ex situ calibration approach could be applied directly without pre-treatment of samples in situ. Rouillon and Taylor (2016) evaluated the analytical capabilities of PXRFS for the measurement of contaminated soil samples, achieving excellent correlation between the ICPAES measurements and the PXRFS results for most elements $\left(e . g . \mathrm{R}^{2}=0.999\right.$ for $\mathrm{Pb}$ and $\mathrm{Mn}$, $\mathrm{R}^{2}>0.995$ for $\mathrm{Zn}, \mathrm{Cd}$, and $\mathrm{Cu}$ ). Both ICP-AES and ICP-MS gave poor measurement accuracy for $\mathrm{Ti}$ and $\mathrm{Cr}$, compared to PXRFS. They concluded that PXRFS is a suitable alternative tool to ICP-AES in the measurement of $\mathrm{Cd}, \mathrm{Cr}, \mathrm{Cu}, \mathrm{Fe}, \mathrm{Mn}, \mathrm{Pb}, \mathrm{Sr}, \mathrm{Ti}$, and $\mathrm{Zn}$ in metal-contaminated soils, and provides a high efficiency solution for high sampling density, cost-effectively for complete geochemical investigations.

XRFS when coupled with multivariate analysis or machine learning becomes a potentially powerful tool for rapid and accurate estimation of PTEs and other soil quality parameters. This is normally called recalibration of the instrument and has been used by several 
researchers to improve the results of XRFS measurement (72-74). For instance, Moros et al. (73) evaluated the feasibility of using partial least squares regression (PLSR) for modelling of XRFS spectra of estuarine sediments to predict the concentrations of $\mathrm{Al}, \mathrm{As}, \mathrm{Cd}, \mathrm{Co}, \mathrm{Cr}, \mathrm{Cu}$, $\mathrm{Fe}, \mathrm{Mg}, \mathrm{Mn}, \mathrm{Ni}, \mathrm{Pb}, \mathrm{Sn}, \mathrm{V}$, and $\mathrm{Zn}$ from 116 samples. They reported an average prediction error of $\pm 37 \%$ for the 14 elements and residual predictive deviation (RPD) values ranged from 1.1 to 3.9. Towett et al. (72) developed simple linear models for estimating total element concentrations of $\mathrm{Al}, \mathrm{Cr}, \mathrm{Cu}, \mathrm{Fe}, \mathrm{Ga}, \mathrm{K}, \mathrm{Mn}, \mathrm{Ni}, \mathrm{Ti}, \mathrm{V}$, and $\mathrm{Zn}$ in soil samples collected from across sub-Saharan Africa using an S2 PICOFOX ${ }^{\mathrm{TM}}$ spectrometer (Bruker AXS Microanalysis GmbH, Germany). The results revealed that XRFS accurately determined the studied total element concentrations $\left(\mathrm{R}^{2}>0.80\right)$. Kaniu et al. (74), used XRFS (with isotope source) spectrometer coupled with PLSR method and artificial neural network (ANN) for non-destructive analysis of soil nutrients needed for soil quality indicator assessment (SQIs). They reported that PLSR was more accurate for analysing $\mathrm{C}, \mathrm{N}, \mathrm{Na}, \mathrm{P}$ and $\mathrm{Zn}\left(\mathrm{R}^{2}>\right.$ 0.9 ) with low standard error of prediction (SEP) of $0.05 \%, 0.01 \%, 0.01 \%$, and $1.98 \mu \mathrm{g} \mathrm{g}^{-1}$, respectively, while for $\mathrm{Mg}, \mathrm{Cu}$ and $\mathrm{Fe}$ the $\mathrm{ANN}$ analysis was better suited with $\mathrm{R}^{2}>0.9$ and SEP of $0.08 \%, 4.02 \mu \mathrm{g} \mathrm{g}^{-1}$, and $0.88 \mu \mathrm{g} \mathrm{g}^{-1}$, respectively. However, these methods have not received sufficient attention in PXRFS measurement. Machine learning can handle the overlapping spectral futures, nonlinearity in the spectral response and matrix effects, generally improving the model prediction accuracy of PTEs, a statement that needs be approved by further research. A summary of case studies that used XRFS for the estimation of PTEs in soil matrices from different regions is presented in Table 1. The majority of reported results are based on specific calibrations provided by the manufacturers of the PXRF devices, whereas only two studies reported recalibration results using spectra analysis with PLSR (75) and cubist regression method (30). 
For PXRFS measurements in Table 1, we see that median $\mathrm{R}^{2}$ values, ranging between 0.91 and 0.98 can be observed in Table 1 for $\mathrm{Zn}, \mathrm{As}, \mathrm{Pb}, \mathrm{Cu}, \mathrm{Cd}, \mathrm{Mn}$, and $\mathrm{Fe}$, whereas less accurate estimations were found for $\mathrm{Cr}$ and $\mathrm{Ni}$ (median $\mathrm{R}^{2}=0.87$ and 0.52 , respectively). The measurement accuracy of $\mathrm{Fe}$ and $\mathrm{Pb}$ is among the highest (median $\mathrm{R}^{2}=0.98$ ). Minimum values of $\mathrm{R}^{2}$ for in situ measurement $\mathrm{As}$ and $\mathrm{Zn}$ were 0.70 and 0.81 , respectively (56). However, the in situ results were rather poor (median $\mathrm{R}^{2}$ of $13 \%$ and $20 \%$ for $\mathrm{Zn}$ and As, respectively), suggesting the former measurement mode can be only used for screening and not for quantitative estimations. Further studies should confirm whether or not the performance of PXRFS can be improved when fresh soil samples are used. Table 1 also shows that accuracy of PXRFS measurements of processed samples (air-drying and sieving) are better than those reported for in situ measurements using fresh soil samples without any sample pre-processing (56).

\subsection{Laser-induced breakdown spectroscopy (LIBS)}

LIBS is one of the most promising tools for elemental analysis $(76,77)$. LIBS is an atomic emission spectroscopy technique whereby a high energy laser (typically $10^{8}-10^{10} \mathrm{~W} / \mathrm{cm}^{2}$ ), usually pulsed, is focused onto a sample surface as a means of generating a plasma with a temperature high enough $(\sim 8000 \mathrm{~K})$ for the ablated material to dissociate and a volume of excited atoms and/or ions expands rapidly into a state of so-called phase relaxation when the atomic and molecular emission lines characteristic of the elements present can be observed $(78,79)$. A charge-coupled detector (CCD) or intensified CCD is subsequently used to collect, spectrally resolve, and detect the light emitted. The detector is gated, deferring detection until the state of phase relaxation is reached - to optimise the signal-to-noise ratio of the acquired spectrums. The individual peaks that characterise the spectrums represent the elements that comprise the sample and consist of three principal parameters: spectral shape, 
wavelength, and intensity. These parameters vary according to the emitting elements but will be modified by the surrounding environment.

LIBS is a reliable technique that can be employed in a range of challenging contexts to directly sample several different material types $(76,77)$. The fact that the laser plasma is formed by specifically directed laser light gives it a range of important properties; e.g. the ability to focus the pulse on a very specific region, thereby creating a specifically defined area for analysis. Such an ability is very useful for a number of different applications, including spatial mapping of elements (micro-analysis). In addition, it is possible not only to transmit the laser pulse via an open-path (line-of-sight), but to use fibre-optics to generate a plasma located on a remote target. As such, it is highly suitable for elemental analysis. Another significant advantage is that LIBS can be merged with other analysis techniques to improve detection competences. It is also possible to improve the excitation capabilities of laser plasma by using auxiliary power sources that remotely add energy into the plasma; for example, a $\mathrm{CO}_{2}$ laser (23).

By generating the LIBS plasma on a sample that is located within a microwave cavity, it is also possible to introduce microwave energy (77). Having the option to improve the emissions that are produced by the elements that form the LIBS plasma represents a significant development because it has the potential to augment detection competences and, through doing so, expand its applicability. Recent signal enhancement schemes such as the double-pulse method (a second laser pulse is timed to "hit" the plasma released by the first pulse, increasing the heating effect and amplifying the signal) and orthogonal pulse method (a second laser is oriented to be orthogonal to the first, and by timing the initial and orthogonal laser pulses even greater signal amplification can be obtained), however, this achieved signal enhancement with double-pulse LIBS in either configuration, they are element and matrix dependent (77). 
The LIBS plasma technique is not without its limitations. For example it is not always possible to control the various operational parameters to optimise the analytical capabilities of LIBS. The ablated mass and nature of the plasma that is generated vary according to the operational parameters that are employed including the distance between the lens and the sample, the power density of the laser pulse, and the pressure and composition of the environment in which the plasma is formed $(77,80)$. The analyte signals are directly influenced by changes in these parameters in addition to the relative intensities of the emission signals. This undermines the effectiveness of the quantitative analyses and ability to use element ratios to identify materials. It is possible to generate LIBS plasma in intense conditions; however, the nature of the conditions has a direct and significant impact on the character of the spectrum changes. In some cases, there may be a requirement for alternate analytical lines and it can be challenging to calibrate for quantitative analysis. The analysis of bulk materials, especially when they are inhomogeneous, can also be challenging due to the minute mass involved in a single LIBS measurement. Effective LIBS analyses that rely on ablation to generate the atomised material followed by the subsequent excitation of the atoms depends on both the sampling, the laser parameters and the physical and chemical properties of the studied sample $(77,81)$. Effects in LIBS play a significant role in quantitative analysis using LIBS include the grain size, moisture content and the chemical matrix effect the on the LIBS emission lines $(77,82)$. This effect is often more severe in LIBS than in ICP methods because of the high density of the materials contained within the small laser plasma (77). Therefore, methods to amend matrix effects in LIBS are very important for quantitative analysis.

LIBS has been employed successfully for the qualitative and quantitative analysis of various elements in samples of diverse origin and nature, including soils $(25,83-85)$. Good calibration results were obtained for the determination of PTE concentrations with detection 
limits in the $10 \mathrm{mg} \mathrm{g}^{-1}$ range. The analysis of PTEs in soils has been investigated using LIBS in combination with established laboratory-based analytical technique such as ICP-OES, ICPMS, GF-AAS, and AAS (86-88). Generally, LIBS-based analysis was reliable and results reasonably correlated with the other traditional analytic methods, encouraging authors to conclude that LIBS is a rapid and useful tool for screening and estimation of PTE contamination $(86,87,89,90)$. For example, the accuracy of LIBS for determining total contents of PTEs (e.g. $\mathrm{Cr}, \mathrm{Cu}, \mathrm{Fe}, \mathrm{Mn}, \mathrm{Ni}, \mathrm{Pb}$ and $\mathrm{Zn}$ ) in 20 reference soil samples has been compared with the results obtained by ICP-AES and AAS methods (86). Results showed that mean values of the relative standard deviation (RSD \%) of metal concentrations measured by LIBS were generally much higher, with the exception of $\mathrm{Cr}$, than the corresponding values obtained by ICP, and are comparable with, or lower than the RSD \% values obtained in other studies. Authors report that the results obtained indicate that PTE concentrations measured by LIBS oscillate much more around the mean value, and often overestimate compared to the corresponding concentrations measured by ICP (86).

Due to the large amount and complexity of the information provided by a LIBS spectrum, chemometric approaches are now commonly used for processing the data (91-93) which open a new avenue for semi-quantitative and quantitative analysis beyond the traditional univariate approach. Several studies have addressed the use of chemometrics for PTEs based on $\operatorname{LIBS}$ spectral data $(24,89,94)$. For example, the estimation of $\mathrm{Al}, \mathrm{Ba}, \mathrm{Ca}, \mathrm{Fe} \mathrm{Mg}, \mathrm{Na}$, and Si in situ has been investigated using 59 measured spectra of weathered terrestrial samples using a portable LIBS instrument in the ultraviolet (UV) and infrared (IR) spectral ranges coupled with a PLSR method (89). The LIBS results were compared with energy depressive X-ray fluorescence spectrometer (ED-XRF) and Raman spectroscopy. The results of LIBSPLSR models for the tested elements ranged between $r$ values of 0.77 (for $\mathrm{Al}$ ) and 0.92 (for $\mathrm{Mg}$ ) in the UV spectral range, and $\mathrm{r}$ values of 0.48 (for $\mathrm{Fe}$ ) and 0.74 (for $\mathrm{Si}$ ) for the IR 
spectral range (89). Authors concluded that the obtained results were in agreement with the range of composition measured by XRFS. LIBS data coupled with an ANN was used for determination of $\mathrm{Cu}$ in 59 spectra from a heterogenic set of reference soil samples and their respective $\mathrm{Cu}$ concentration (24). The $\mathrm{ANN}$ provided remarkable prediction accuracy for $\mathrm{Cu}$, although portable instrumentation was employed. The authors reported a limit of detection (LOD) of $2.3 \mathrm{mg} \mathrm{dm}{ }^{-3}$ of $\mathrm{Cu}$ and a mean squared error (MSE) of $0.5 \mathrm{mg} \mathrm{dm}^{-3}$ for the predictions (24). The performance of LIBS spectral data for determination of Cd under air and Argon (Ar) conditions were analysed and compared (94). PLSR and least-squares support vector machine (LS-SVM) models of Cd under both conditions were constructed. Results showed that the LS-SVM model for an Ar environment provided the best performance of prediction with $\mathrm{R}^{2}$ of 0.98 , and root mean square error of prediction (RMSEP) of $0.034 \mathrm{mg} \mathrm{kg}^{-1}$. The authors concluded that LIBS combined with LS-SVM for an Ar environment condition could be a useful tool for the accurate prediction of $\mathrm{Cd}$ for environmental monitoring (94).

Table 1 summarizes some of the available studies on the application LIBS for predicting PTEs in the soils. Compared with XRFS, few papers are available reporting results obtained by LIBS. The use of multivariate statistical analyses is still limited to the commonly used PLSR, with a very limited application of machine learning methods (94). Spectral data preprocessing is not regularly applied, although standard normal variate (SNV) and wavelet methods are used to correct the spectral information, and reduce noise in order to improve the prediction performance (89). The highest correlation coefficients were found for the total concentrations of $\mathrm{Zn}(0.99), \mathrm{Pb}(0.99)$, and $\mathrm{Cu}(0.98)$ (25). LIBS can also be used for mobile, and rapid semi-quantitative analysis and screening of PTEs in soils using the traditional calibration curve method (25). 


\subsection{Visible and near-infrared spectroscopy (Vis-NIRS)}

Visible and near-infrared (Vis-NIR) spectroscopy has proved to be a useful tool for soil analysis (95). Once a soil medium is subjected to a light source, part of the light is absorbed, part is scattered and part diffusely reflected from the soil. The final shape of the soil spectra is a reflection of both the light scattering and absorption phenomena that differs due to the sample physical and chemical characteristics, respectively. The working principle of the absorption Vis-NIR spectroscopy stems from activating chemical bonds by irradiating mineral mixtures thereby creating resonance vibration, either by bending or stretching of the molecular bonds. These types of vibrations result in light absorption, in different levels, having a particular power quantum related to the difference between two energy levels. Since the energy quantum is actually straight-forwardly associated with frequency, the resulting absorption features of the spectrum curve can be used for analytical purposes (95). In the visible (Vis) range (400-780 $\mathrm{nm}$ ), absorption bands related to soil colour are due to electron excitations, which assists the measurement of soil organic matter content (SOM) and moisture content $(\mathrm{MC})$. Within the NIR range $(780-2500 \mathrm{~nm})$, overtones of $\mathrm{OH}$ and overtones and combinations of $\mathrm{C}-\mathrm{H}+\mathrm{C}-\mathrm{H}, \mathrm{C}-\mathrm{H}+\mathrm{C}-\mathrm{C}, \mathrm{OH}^{+}$minerals, and $\mathrm{N}-\mathrm{H}$ of fundamental vibrations (e.g., $\mathrm{C}-\mathrm{H}, \mathrm{N}-\mathrm{H}, \mathrm{O}-\mathrm{H}, \mathrm{C}-\mathrm{O}, \mathrm{Si}-\mathrm{O}$ ) that occur in the MIR spectral range $\left(2500-25000 \mathrm{~nm}\right.$ or wave number of $\left.4000-400 \mathrm{~cm}^{-1}\right)(96,97)$. These are the major spectral features essential for the detection and quantification of key soil properties having direct spectral responses e.g., MC, SOM, clay minerals, and total nitrogen (98). These properties can be accurately predicted with Vis-NIRS with appreciable accuracy, compared to properties with indirect spectral responses (e.g., $\mathrm{P}, \mathrm{K}, \mathrm{Mg}, \mathrm{Ca}, \mathrm{Na}, \mathrm{CEC}, \mathrm{pH}$ ) that are potentially predictable through covariation with properties having direct spectral responses in the Vis-NIR spectral range (95). The NIR overtones and combinations are of broad bands that overlap but 10-100 times weaker compared with the MIR spectrum where fundamentals are more 
resolved, permitting the structure of a sample to be better elucidated $(95,99,100)$. The higher energy of NIR radiation and the relatively low absorptivity of water makes NIR spectroscopy as a better technique when wet soils and sediments samples are analysed, compared with MIR spectroscopy $(99,100)$. Due to the overlaps among overtones and combinations due to their broad bands, advanced chemometrics and machine learning tools are used to extract quantitative and qualitative information. Overall, Vis-NIRS is widely adopted to determine SOM, minerals, texture, nutrients, and PTEs in soils $(95,100)$.

The potential of NIR reflectance spectroscopy coupled with PLSR was investigated by Kooistra et al. (101) for the assessment of soil contaminated by $\mathrm{Cd}$ and $\mathrm{Zn}$ in river floodplains in the Netherlands (101). The authors reported a coefficient of determination $\left(\mathrm{R}^{2}\right)$ of 0.88 and 0.90 and root mean square error in cross validation (RMSECV) of 0.68 and 80.97 $\mathrm{mg} \mathrm{kg}^{-1}$, for $\mathrm{Cd}$ and $\mathrm{Zn}$, respectively. Also, the prediction of PET (As, $\mathrm{Cd}, \mathrm{Cu}, \mathrm{Fe}, \mathrm{Hg}, \mathrm{Pb}, \mathrm{S}$, $\mathrm{Sb}$, and $\mathrm{Zn}$ ) concentrations in soil samples was performed based on Vis-NIRS coupled with an ANN and stepwise multiple linear regression analysis (SMLR) (7). The authors reported high prediction accuracy results for six out of the nine elements, with $\mathrm{R}^{2}$ values of $0.84,0.72$, 0.96, $0.95,0.87$ and 0.93 for $\mathrm{As}, \mathrm{Fe}, \mathrm{Hg}, \mathrm{Pb}, \mathrm{S}$, and $\mathrm{Sb}$, respectively, for SMLR. No successful correlations were obtained for $\mathrm{Cd}(0.51), \mathrm{Cu}(0.43)$, and $\mathrm{Zn}(0.24)$. Siebielec et al. (102) based on full Vis-NIR spectra $(400-2500 \mathrm{~nm})$ of soil samples collected from a wide range of $\mathrm{pH}$, organic carbon and soil textures, reported good prediction using PLSR models with $\mathrm{R}^{2}$ of $0.97,0.94,0.80,0.99$ and 0.96 for $\mathrm{Fe}, \mathrm{Cd}, \mathrm{Cu}, \mathrm{Ni}$ and $\mathrm{Zn}$, respectively. Wu et al. (103) used a Vis-NIR spectrometer coupled with univariate regression and principal component regression (PCR) analyses for predicting $\mathrm{Hg}$ concentration in agricultural soils from the Nanjing region in China. The authors used some pre-treatments such as KubelkaMunk transformations, absorbance and derivative to optimize the prediction of $\mathrm{Hg}$ concentration, achieving the best results by using the PCR regression with the Kubelka- 
Munk transformation with $\mathrm{R}^{2}$ of 0.69 , and RMSEP of $0.15 \mathrm{mg} \mathrm{kg}^{-1}$. They found a positive correlation between $\mathrm{Hg}$ concentration and the absorption of goethite and clay minerals, and they suggested that $\mathrm{Hg}$-sorption by clay-size mineral aggregates in soils was the mechanism explaining the successful prediction of $\mathrm{Hg}$ having spectral featureless (103). The capability of Vis-NIRS (400-2,500 nm) coupled with PLSR was evaluated for the measurement of AS in forest soil (104). PLSR was also used to estimate AS concertation in soil samples (105), reporting $\mathrm{R}^{2}$ of $0.69-0.71$, RMSEP of $1.64-1.61$ and RPD of $1.70-1.80$ for the best calibration model. Authors pointed out the impact of soil organic matter (OM) content on the model prediction accuracy. Estimating and mapping the distribution of PTEs in soils using Vis-NIRS combined with SMLR and enter-MLR (EMLR) was conducted by Choe et al. (106). The best results for predicting $\mathrm{AS}$ and $\mathrm{Cu}$ were achieved with EMLR models with $\mathrm{R}^{2}$ values of 0.60 and 0.81 , respectively. The authors provided a distribution map (contours) of As and $\mathrm{Cu}$ concentrations resulting from the EMLR models, which exhibited identical spatial patterns to a map produced based on the reference measured values of $\mathrm{As}$ and $\mathrm{Cu}(106)$.

In order to better predict low concentrations of $\mathrm{As}, \mathrm{Cu}, \mathrm{Pb}$, and $\mathrm{Zn}$ metals in agricultural soils, a comparison was made between PLSR and genetic Algorithm-PLSR (GA-PLSR) has been made (107). Results showed that the GA-PLSR model outperformed the PLSR models with $\mathrm{R}^{2}$ of cross-validation $\left(\mathrm{R}^{2} \mathrm{cv}\right)$ of $0.60-0.69$ for the four metals analysed while the $\mathrm{R}^{2} \mathrm{cv}$ of PLSR ranged between 0.49 and 0.58 (107). The authors attributed the Vis-NIRS measurement of studied PTE (having no direct spectral responses) to be due to co-variation with $\mathrm{OM}$, as both heavy metals and $\mathrm{OM}$ have the same spectral features (e.g., same significant wavelengths) (107). The feasibility of using Vis-NIRS to predict PTEs (Cr, Zn, $\mathrm{Cu}, \mathrm{Ni}$, and $\mathrm{Pb}$ ) in several soil types using PLSR was reported for a collection of samples from Bulgaria (27). The results revealed that the best prediction obtained was with the $\mathrm{Cu}$ model. However, the prediction of $\mathrm{Zn}, \mathrm{Pb}$ and $\mathrm{Ni}$ models were less accurate, and the results 
for $\mathrm{Cr}$ in both cross-validation and prediction were the worst (27). The authors found that the values of both RMSECV and RMSEP increased when the number of samples in the calibration set (cross-validation) was decreased. They concluded that Vis-NIRS is a useful tool to predict PTEs in soil samples, on the condition that a large number of samples was used in the calibration. A case study to monitor the suitability of Vis-NIRS for predicting concentration of PTEs based on PLSR and support vector machine regression (SVMR), using samples from mining dumpsites in the Czech Republic was reported in (108). The best prediction of As was obtained with the SVMR model with the first derivative pre-treatment $\left(\mathrm{R}^{2}=0.89, \mathrm{RMSEP}=1.89 \mathrm{mg} \mathrm{kg}^{-1}, \mathrm{RPD}=2.63\right)$, where acceptable prediction was obtained for $\mathrm{Cd}$ and $\mathrm{Cu}\left(\mathrm{R}^{2}=0.66\right.$ and $0.81, \mathrm{RMSEP}=0.0 .8$ and $4.08 \mathrm{mg} \mathrm{kg}^{-1}, \mathrm{RPD}=2.0$ and 2.5, respectively).

Vis-NIRS has been reported as a rapid, non-destructive and cost-effective tool for estimating the concentration of PTEs in soil $(3,16)$. Nevertheless, the actual correlations obtained between Vis-NIR spectra and the PTEs are not necessary based on the direct response of these element in the Vis-NIR spectrum $(3,16)$. The majority of the reported studies have proposed that the calibrations obtained were based on indirect correlations, between the measured metals and other soil properties, having direct spectral features in the NIR spectral range such as clay, organic carbon, and iron oxides $(3,16,109)$. Therefore, caution is necessary before applying the contaminate-based model to a different sample matrix.

Wu et al. (109) explored the impact associated with surrogate calibrations. The authors compared soil samples naturally rich in $\mathrm{Cd}$ and $\mathrm{Zn}$ with the spiked soil samples with $\mathrm{Cu}$ and $\mathrm{Zn}$, concluding that the Vis-NIR spectrum is sensitive to sample handling as wells as the orientation of the sample relative to the Vis-NIR instrument. They could not find distinguishable effect in respect of the presence of PTEs on the Vis-NIR spectrum (109), which supports the hypothesis of "surrogate" correlation for PTEs, and suggests that even in 
highly contaminated soils PTEs may not be identifiable over the OM absorption bands in the Vis-NIRS region (109). However, there are several cases of successful application of NIR spectroscopy to measure PTEs in soils, which necessitates further research to explain the physico-chemical relations between the PTEs and other soil properties (e.g., SOM, and clay minerals), having a direct spectral response in the NIR spectral range.

Previous research has shown that sample preparation (drying, grinding, sieving) before scanning with NIR spectroscopy affected the measurement accuracy of soil fertility parameters (95). Likewise for PTEs, according to published literature sample preparation has a clear effect on measurements. The effect of sample preparation such as homogenization, drying, grinding, and sieving on estimating the accuracy of cyanide concentration using a hand held NIR instrument and PLSR was investigated by Sut et al. (110). The authors found that the root mean square error of measured cyanide concentrations was larger for unprepared fresh soil samples (RMSE $>2400 \mathrm{mg} \mathrm{kg}^{-1}$ ), compared to prepared samples in the laboratory $\left(\right.$ RMSE $\left.>1750 \mathrm{mg} \mathrm{kg}^{-1}\right)$. They concluded that the direct in situ measurements yielded high a LOD, which, in laboratory, can be improved by sample preparation, with the sample preparation actually resulting in reducing the influences of light scattering, soil moisture and particle size on accuracy of measurement. They also found that the prediction of cyanide concentration in processed soil samples (dried and sieved) $\left(\mathrm{R}^{2}=0.41\right)$ was improved after grinding $\left(\mathrm{R}^{2}=0.86\right)$

More case studies concerning the use of NIR spectroscopy for the estimation of PTEs in soil matrices are provided in Table 1 for different countries over the world. The full Vis-NIR spectral range of 350-2500 $\mathrm{nm}$ was used in the majority of the reported studies. Spectral data pre-processing was used intensively to improve the prediction results, among which the first derivative (FD) and continuum removal (CR) methods were the most used. The PLSR linear multivariate analysis was the most common method used for modelling. In general, 
comparable prediction accuracies were found for the chalcophile elements $(\mathrm{As}, \mathrm{Cu}, \mathrm{Pb}$ and $\mathrm{Zn})$, compared to the siderophile elements $(\mathrm{Co}, \mathrm{Fe}, \mathrm{Mn}$ and $\mathrm{Ni})$. The highest prediction performance was for the total concentrations of $\mathrm{Pb}\left(\mathrm{R}^{2}=0.94\right)$ and $\mathrm{Ni}\left(\mathrm{R}^{2}=0.93\right)$ (Table 1$)$. The successful prediction of these elements can be attributed to the relationship between these elements and carbonate (111). Fe minerals are the main parameter determining the prediction accuracy $(7,103,112)$, in addition to clay minerals and SOM $(102,113)$, all having direct spectral responses in the NIR range (95).

\subsection{Mid-infrared spectroscopy (MIRS)}

MIRS is a rapid and cost-effective techniques developed over the last 40 years for soil analysis (114). Fundamental vibrations of chemical bonds e.g., $\mathrm{C}-\mathrm{H}, \mathrm{N}-\mathrm{H}, \mathrm{O}-\mathrm{H}, \mathrm{C}-\mathrm{O}, \mathrm{Si}-\mathrm{O}$ take place in the MIR electromagnetic range (2500-25000 nm or wave number of $4000-400$ $\mathrm{cm}^{-1}$ ) (97), and can provide extensive and wealth information about the chemical and physical properties of the sample components (115). The MIRS spectra can reveal essential information related to both organic and some inorganic compounds. However, the complexity of soil matrices, and the relatively low concentrations of PTEs usually do not show absorption features in MIR spectrum (16), but they are bound to spectrally active soil components (e.g., OM and clay minerals) and as a result modify the resultant spectral features (21). However, compared to the Vis-NIRS, the MIRS offers more informative spectrum with well delineated absorption bands $(97,116)$. By using MIRS, it has been demonstrated that particular markers exist in soil MIR spectrum for minerals and organometallic complexes (117).

Many reports on the use of MIRS for the measurement of key soil physical and chemical properties can be found in the literature. For example, MIRS has been successfully used to estimate soil total carbon, organic, and inorganic carbon, providing more accurate estimations than Vis-NIRS $(118,119)$. Recent research has revealed that the MIR can be used to measure 
PTEs in soil $(97,102)$. In their study, Siebielec et al. (102) used 70 soil samples collected from the mining area of Tarnowskie Gory (Upper Silesia, Poland) for predicting $\mathrm{Fe}, \mathrm{Cd}, \mathrm{Cu}$, $\mathrm{Ni}, \mathrm{Zn}$, and $\mathrm{Pb}$ concentrations based on the combined spectral range of NIRS and MIR spectra (2500 to $25000 \mathrm{~nm}$ ) coupled with the leave-one-out PLSR cross-validation procedure. They achieved accurate calibrations between $\mathrm{Fe}, \mathrm{Cd}, \mathrm{Cu}, \mathrm{Ni}$, and $\mathrm{Zn}$ and MIR spectra with $\mathrm{R}^{2}$ of $0.97,0.94,0.80,0.99$, and 0.96 for those metals, respectively, but $\mathrm{Pb}$ had a low correlation with $\mathrm{R}^{2}=0.66$, and the calibrations using NIRS were less accurate tan those based on MIR. By testing 4130 European agricultural soils, Soriano-Disla et al. (97) found that that MIRS was a powerful tool for predicting the concentrations of PTEs in soil. Given that the bioavailability of PTEs in soil is basically ruled through the interactions between the trace elements species and existing anionic functional groups, the MIRS method can be used successfully for estimation PTEs bioavailability. The feasibility of using MIR to determine Cr using tannery sludge in tropical soils has been tested (120). The authors reported changes in soil spectral signal due to metal adsorption to soil components, demonstrating differences between relatively contaminated-free and highly contaminated soils. The authors pointed out that MIRS outperformed Vis-NIRS for measuring Cr, suggesting that the OM content played a more substantial role of the determination of spectral characteristics than mineralogical compositions, especially those that have high OC content. Very recently, the feasibility of Vis-NIRS and MIRS handheld (In particular the 4300 Handheld Fourier Transform Infrared (FTIR) Spectrophotometer) for quantification of PTEs (Al, As, Ca, Cu, Fe, K, Mn, Na, Ni, $\mathrm{Pb}$, and $\mathrm{Zn}$ ) in 203 soil samples collected from Saxony, Germany, were investigated (21). The authors used PLSR methods with different spectral data pre-processing, namely, first and second derivatives, multi scatter correction (MSC), continuum removal (CR) and standard normal variate (SNV). The authors reported a high performance for the model of MIR-spectra with multi-scatter correction (MSC), and SNV-pre-processing with very good to good 
prediction for $\mathrm{Al}, \mathrm{Fe}, \mathrm{K}$ and $\mathrm{Ni}$ models $\left(\mathrm{R}^{2}=0.70-0.88\right)$. It was concluded that $\mathrm{MIR}$ spectroscopy is a reliable and promising alternative approach for the estimation of metal contents in soil. Table 1 summarizes the most important studies on applying the MIRS for predicting PTEs in soil. Compared with Vis-NIRS, few articles are available reporting predictions of PTE concentrations in soils by MIRS. A wide range of pre-processing methods (e.g., CR, MSC, and SNV) were used to correct the spectral information, reduce noise and scattering effects, to improve the prediction performance. In general, PLSR was the common calibration method. Better predictions were found for the total concentrations of siderophile elements, compared to the chalcophile elements (see Table 1). The highest correlation coefficients were found for the total concentrations of $\mathrm{Ni}\left(\mathrm{R}^{2}=0.98\right), \mathrm{Zn}(0.96)$, and As (0.92) (21). The successful prediction of these elements can be attributed to the fact that the spectral features in the MIR-region are mainly caused by fundamental molecular vibrations (21).

\section{(Table 1)}

\section{Data and model fusion methods}

Soil studies are usually considered as a multifactorial problem and it is worth exploring and measuring the same samples simultaneously using several analytical tools (platforms) processing with on or a set of models. Although research on individual proximal sensors has demonstrated potential, no individual sensor (or technique) is able to completely characterize soil complexity. Soils are typically characterized by high variability on all scales that can be monitored using different sensor systems. Each sensor offers an exclusive perspective on one aspect of a soil system that will change both temporally and spatially. Consequently, requiring a single sensor to perform more than one function in these circumstances is almost unfeasible (136). Data fusion is the combination of data from different sources to produce more rigorous data than could be obtained from a single system or sensor (16). Sensor fusion 
can be a sensible option to integrate diverse variations across scales and different soil properties. Multi-model fusion or ensemble methods are a useful tool for improving predictions, and the data fusion approach has been applied extensively in agriculture in recent years (137-139). Such an approach has not been yet tested for PTE analysis but sensor data and multi-model fusion methods have the potential to improve performance when estimating PTEs in soil using various complementary sensors and a set of rigorous models.

The optimal goal of the fusion technique is to gain high quality and reliable information, providing better and greater in-depth understanding (140). Fusion techniques are expected to deduce inferences that are potentially more accurate than if they were achieved by a single sensor or model. Fusion of data from multiple sensors and/or sets of models provides several advantages over data from a single sensor such as robustness, accuracy, extended feature coverage and harmonizing information on particular phenomena $(30,140,141)$. The fusion technique can be categorized into two major types: (1) proximal sensor data fusion in which data from different sensors are applied jointly into to a single multivariate or machine learning method; (2) multi-model fusion, in which models are combined to provide the optimal prediction. (see Fig.1).

Measuring with multiple sensors such as portable/handheld Vis-NIRS, MIRS, and PXRFS is versatile and provides a larger amount of data. This progress in data acquisition offers the possibility of a better understanding of soil contamination and improved analysis. Vis-NIRS, MIRS, and PXRFS have been used independently for determination of PTEs in soil sample data, but model fusion is still new in environmental studies particularly, for PTE determination, and has attracted no or little attention in the literature. Wang et al. (29) successfully combined Vis-NIRS and PXRFS for the quantification of soil nitrogen and carbon. Likewise, Chakraborty et al. (142) combined Vis-NIRS spectra and PXRFS to 
develop an optimised model for the rapid prediction of petroleum hydrocarbons in soils. Towett et al. (143) combined MIRS and PXRFS to predict soil properties and distributions of available $\mathrm{Al}, \mathrm{Cu}, \mathrm{Fe}, \mathrm{Zn}$ and $\mathrm{Mn}$ from sub-Saharan Africa soils using $\mathrm{RF}$ regression. The authors reported a very good prediction for $\mathrm{Al}\left(\mathrm{R}^{2}=0.86\right)$, poor prediction for $\mathrm{Mn}\left(\mathrm{R}^{2}=\right.$ $0.56)$, and very poor predictions for $\mathrm{Cu}, \mathrm{Fe}$, and $\mathrm{Zn}\left(\mathrm{R}^{2}=0.43,0.40\right.$, and 0.04 , respectively). The authors found that the prediction of some elements was strongly improved by adding XRFS data to the MIR data.

Multi-model fusion can improve the overall model prediction accuracy. Combining different model outcomes in this way is termed as model ensemble or averaging (144). This combination of models reduces the variances of predictions found with individual models, hence, the combined predictions typically outperform those from individual models. The majority rule (simple averaging) is the common model fusion technique, which integrates all models by using an equally weighted averaging technique that integrates several ensemble methods (141). For instance, Chakraborty et al. (142) applied a model fusion technique by using Vis-NIR based penalized spline regression (PSR) method followed by PXRFS elemental based RF regression, which resulted in improved prediction accuracy of total petroleum hydrocarbon (TPH) estimation in contaminated soil. The PSR was used to fit the training set (containing Vis-NIR spectra only) and RF was used to fit the residual of the PXRF elemental data. The authors found that the combined modelling approach produced better results compared to individual model outputs. In another study, O'Rourke et al. (30) investigated the combined approach of Vis-NIRS, MIRS, and PXRF data to improve the accuracy in estimating PTEs in soil. These authors again found integration between VisNIRS, MIRS, and PXRFS resulted in better determination of (As, $\mathrm{Cd}, \mathrm{Co}, \mathrm{Cu}, \mathrm{Hg}, \mathrm{Mn}, \mathrm{Ni}$, and $\mathrm{Zn}$ ) distributions in soil than could be obtained using any one spectral method. The authors further argued that the multi-sensor data fusion approach can be an alternative to 
traditional wet chemistry analyses, and is potentially suited for large scale routine soil monitoring.

\section{(Figure 1)}

\section{Selecting of optimal optical technique for PTE analysis}

In order to select the most suitable optical technique for the determination of PTEs in soil, information such as analysis time, cost per sample, portability and ease of field application, robustness, repeatability, prediction accuracy and the final application of results should be available. One example is, when time is not a significant issue and accuracy is of prime importance, here laboratory techniques are the ideal option, as their accuracy is higher than portable field devices. However, in this case pre-processing of soil samples could also enhance the prediction accuracy and enable more reliable results to be obtained.

With recent advances in proximal soil sensing and data mining techniques, portable field equipment is now available that can carry out measurements in situ for rapid detection and screening with good to acceptable accuracy. However, it is important to note that there are many challenges associated with field spectroscopy, among others, surface roughness, texture, moisture content, plant residues and gravels are the parameters with the most negative effects. Compared to laboratory spectroscopy, field spectroscopy requires extra attention to eliminate the effects of external (environmental) variables. Recent advances in pre-processing algorithms to eliminate these external factors, such as external parameter orthogonalization (EPO) and direct standardization (DS) are recommended by many studies $(145,146)$. Moreover, data mining techniques such as machine learning methods when combined with EPO and/or DS can deal with both linear and non-linear sources in the data set and improve prediction accuracy $(95,147,148)$. It can be hypothesised that the 
combination of multi-sensors using data fusion approach together with EPO and DS is the ultimate solution for optimal prediction accuracy for in situ measurement of PTEs. Future work is needed to confirm this assumption, although developments in agriculture has already demonstrated its general validity.

For decision-making, important factors such as analysis run time, cost per sample, operational skills required and portability need to be considered. The portable vis-NIRS, MIRS, LIBS, and PXRFS are cost-effective, time-saving, and provide sufficient accuracy in screening and monitoring PTE contamination levels in soil when compared to laboratory analytical methods $(16,21)$. Portable field measuring techniques enable the collection of a high number of samples that can cover the entire contaminated area in a relatively short period, which is crucial for effective hazard assessment and remediation action planning (149-151). High-resolution sampling offers a better understanding of the spatial distribution of the area being studied by using geostatistical spatial interpolation and the Geographic Information System as a mapping tool. This offers accurate elemental maps and derivation of interpretive hazard maps for rapid and accurate remediation actions (151). In this context, Suh et al. (150) developed an inexpensive, rapid and accurate mapping system for soil subjected to $\mathrm{Cu}$ contamination using in situ PXRFS data corrected by reference $\mathrm{Cu}$ values obtained from ICP-AES analysis at a mine site in South Korea. The authors reported accurate prediction of $\mathrm{Cu}$ concentrations similar to those of ICP-AES with an excellent $\mathrm{R}^{2}$ values of 0.99. They concluded that the method is effective for mapping soil contamination if the PXRFS databases and laboratory measurement (e.g., ICP-AES) are integrated (150). One example of potential use of portable sensors is fusion between PXRFS and portable vis-NIRS data for accurate and rapid prediction of PTEs (75), which can be integrated with satellite and unmanned aerial vehicle-based hyperspectral imagining systems for large scale investigations $(152,153)$. 
Table 2 shows the main factors to be considered in the decision-making process when selecting analytical techniques for PTEs analysis. These factors can be linked to cost (device and sample), detection (targeted analytes and LOD), the measurement scale, and the operator's skills. For example, the LIBS provides a wide range of analysis (more than 20 elements) at acceptable LOD (1-10 $\left.\mathrm{mg} \mathrm{g}^{-1}\right)$. However, the initial cost for the device $(\$ 35,000-50,000)$, the cost per sample (\$15-30), and the fact this a non-established handheld/portable device for in situ measurements, limit the use of such a method for field measurement.

On the other hand, portable spectroscopy systems such as vis-NIRS, MIRS, and PXRF are of much lower instrument cost $(\$ 30,000-40,000)$ with per sample cost $(\$ 10-20)$ (Table 2$)$. The targeted analytes of these portable techniques cover the majority of PTEs (26 elements), with PXRFS able to provide real-time measurement in the field with good accuracy $\left(\mathrm{R}^{2}=0.80\right)$ (56). Regarding operational skills, vis-NIRS, MIRS and PXRF spectroscopy all require low to medium skills, whereas laboratory methods such as ICP-MS, OES, and AES require medium to high skills, and NAA requires a high level of skill. This highlights an advantage for portable techniques in that they do not need highly expert personnel for in situ measurement and to provide hazard maps in less than one day (150).

\section{(Table 2)}

\section{Conclusions}

There are several well-established standard laboratory techniques for determining the concentration and distribution of potentially toxic elements (PTEs) in soils. The methods offer a diverse sensitivity range, are highly accurate down to trace level detection. However, there are drawbacks such as sample extraction and analytical time required, cost, and relatively high level of technical expertise needed. Thus there is a growing 
demand for in situ and real-time detection/measurement tool. This has contributed to the development of new portable/handheld devices such as visible and near infrared (VisNIR), mid infrared (MIR), laser-induced breakdown spectroscopy (LIBS), and X-ray fluorescence (XRF) spectrometry, which offer rapid measurement and allow for the high density sampling necessary for quantification and mapping of PTEs to support decisions for e.g., land reclamation. However, there are still limitations related to soil matrix properties such as variation in moisture content and soil texture that can reduce the prediction accuracy. To overcome these issues, advanced pre-processing algorithms such the external parameter orthogonalization (EPO) and direct standardization (DS) coupled with machine learning techniques such as support vector machine (SVM) or the random forest (RF) can be used. An artificial neural network (ANN) that can cope with nonlinearities in the spectral responses of the soil can eliminate the influence of these variables and improve prediction accuracy. Moreover, data fusion technique that merge data from different sensors, or predictions of different models, can improve estimation accuracy. However, much research is still needed in the area of portability and real-time prediction based on spectroscopic techniques that can speed up the field measurement, and maybe revolutionise the way we conduct risk assessment or site investigation.

\section{Acknowledgements}

The authors acknowledge the financial support received from the Research Foundation Flanders (FWO), Odysseus Project (No. G0F9216N). 


\section{References}

1. Khan, S., Cao, Q., Zheng, Y. M., Huang, Y. Z., and Zhu, Y. G. (2008) Health risks of heavy metals in contaminated soils and food crops irrigated with wastewater in Beijing, China. Environ. Pollut. 152 (3): 686-692.

2. Zhang, X. Y., Lin, F. F., Wong, M. T. F., Feng, X. L., and Wang, K. (2009) Identification of soil heavy metal sources from anthropogenic activities and pollution assessment of Fuyang County, China. Environ. Monit. Assess. 154 (1-4): 439-49.

3. Shi, T., Chen, Y., Liu, Y., and Wu, G. (2014) Visible and near-infrared reflectance spectroscopy - An alternative for monitoring soil contamination by heavy metals: a review. J. Hazard. Mater. 265: 166-176.

4. Vodyanitskii, Y. N. (2016) Standards for the contents of heavy metals in soils of some states. Ann. Agrar. Sci. 14 (3): 257-263.

5. Alloway, B. J. (2013) Sources of Heavy Metals and Metalloids in Soils. In Heavy Metals in Soils, Alloway, B.J., Ed., Springer Berlin Heidelberg, pp 11-50.

6. GWRTAC. (1997) Remediation of Metals-Contaminated Soils and Groundwater: Technology Evaluation Report. Available at: http://citeseerx.ist.psu.edu/viewdoc/download?doi=10.1.1.401.3768\&rep=rep1\&type= pdf (accessed 1 January 2018).

7. Kemper, T., and Sommer, S. (2002) Estimate of heavy metal contamination in soils after a mining accident using reflectance spectroscopy. Environ. Sci. Technol. 36 (12): $2742-2747$.

8. Tuzen, M., Melek, E., and Soylak, M. (2006) Celtek clay as sorbent for separationpreconcentration of metal ions from environmental samples. J. Hazard. Mater. 136 (3): 597-603.

9. Vieira, C., Morais, S., Ramos, S., Delerue-Matos, C., and Oliveira, M. B. P. P. (2011) Mercury, cadmium, lead and arsenic levels in three pelagic fish species from the Atlantic Ocean: Intra- and inter-specific variability and human health risks for consumption. Food Chem. Toxicol. 49 (4): 923-932.

10. Jomova, K., and Valko, M. (2011) Advances in metal-induced oxidative stress and human disease. Toxicology 283 (2-3): 65-87.

11. Tokar, E. J., Benbrahim-Tallaa, L., and Waalkes, M. P. (2011) Metal ions in human cancer development. Met. Ions Life Sci. 8: 375-401.

12. Cui, L., Wu, J., and Ju, H. (2015) Electrochemical sensing of heavy metal ions with inorganic, organic and bio-materials. Biosens. Bioelectron. 63: 276-286.

13. Bansod, B., Kumar, T., Thakur, R., Rana, S., and Singh, I. (2017) A review on various electrochemical techniques for heavy metal ions detection with different sensing platforms. Biosens. Bioelectron. 94: 443-455.

14. Yuanyuan, L., Xinqiang, L., Niyungeko, C., Junjie, Z., and Guangming, T. (2017) A review of the identification and detection of heavy metal ions in the environment by 
voltammetry. Talanta 178 (August 2017): 324-338.

15. Soodan, R. K., Pakade, Y. B., Nagpal, A., and Katnoria, J. K. (2014) Analytical techniques for estimation of heavy metals in soil ecosystem: A tabulated review. Talanta 125: 405-410.

16. Horta, A., Malone, B., Stockmann, U., Minasny, B., Bishop, T. F. A., McBratney, A. B., Pallasser, R., and Pozza, L. (2015) Potential of integrated field spectroscopy and spatial analysis for enhanced assessment of soil contamination: A prospective review. Geoderma 241-242: 180-209.

17. Douglas, R. K., Nawar, S., Alamar, M. C., Coulon, F., Mouazen, A. M., Nawar, S., Alamar, M. C., Coulon, F., and Mouazen, A. M. (2017) Almost 25 years of chromatographic and spectroscopic analytical method development for petroleum hydrocarbons analysis in soil and sediment: state-of-the-art, progress and trends. Crit. Rev. Environ. Sci. Technol. 47 (16): 1497-1527.

18. Rossel, R. A. V., Adamchuk, V. I. I., Sudduth, K. A. A., McKenzie, N. J. J., Lobsey, C., Viscarra Rossel, R. A. A., Adamchuk, V. I. I., Sudduth, K. A. A., McKenzie, N. J. J., and Lobsey, C. (2011) Proximal Soil Sensing. An Effective Approach for Soil Measurements in Space and Time. 1st ed. Elsevier Inc.

19. Weindorf, D., Bakr, N., and Zhu, Y. (2014) Advances in Portable X-ray Fluorescence (PXRF) for Environmental, Pedological, and Agronomic Applications. In Advances in Agronomy, Academic Press, pp 1-45.

20. He, Y., Tang, L., Wu, X., Hou, X., and Lee, Y. (2007) Spectroscopy: The Best Way Toward Green Analytical Chemistry? Appl. Spectrosc. Rev. 42 (2): 119-138.

21. Riedel, F., Denk, M., Müller, I., Barth, N., and Gläßer, C. (2018) Prediction of soil parameters using the spectral range between 350 and 15,000 nm: A case study based on the Permanent Soil Monitoring Program in Saxony, Germany. Geoderma 315: 188198.

22. Rouillon, M., and Taylor, M. P. (2016) Can field portable X-ray fluorescence (pXRF) produce high quality data for application in environmental contamination research? Environ. Pollut. 214: 255-264.

23. Bousquet, B., Travaillé, G., Ismaël, A., Canioni, L., Michel-Le Pierrès, K., Brasseur, E., Roy, S., le Hecho, I., Larregieu, M., Tellier, S., Potin-Gautier, M., Boriachon, T., Wazen, P., Diard, A., and Belbèze, S. (2008) Development of a mobile system based on laser-induced breakdown spectroscopy and dedicated to in situ analysis of polluted soils. Spectrochim. Acta - Part B At. Spectrosc. 63 (10): 1085-1090.

24. Ferreira, E. C., Milori, D. M. B. P., Ferreira, E. J., Da Silva, R. M., and Martin-Neto, L. (2008) Artificial neural network for $\mathrm{Cu}$ quantitative determination in soil using a portable Laser Induced Breakdown Spectroscopy system. Spectrochim. Acta - Part B At. Spectrosc. 63 (10): 1216-1220.

25. Meng, D., Zhao, N., Ma, M., Fang, L., Gu, Y., Jia, Y., Liu, J., and Liu, W. (2017) Application of a mobile laser-induced breakdown spectroscopy system to detect heavy metal elements in soil. Appl. Opt. 56 (18): 5204-5210. 
26. Cozzolino, D. (2016) Near infrared spectroscopy as a tool to monitor contaminants in soil, sediments and water-State of the art, advantages and pitfalls. Trends Environ. Anal. Chem. 9: 1-7.

27. Todorova, M., Mouazen, A. M., Lange, H., and Atanassova, S. (2014) Potential of Near-Infrared Spectroscopy for Measurement of Heavy Metals in Soil as Affected by Calibration Set Size. Water, Air, Soil Pollut. 225 (8): 225:2036.

28. Kuang, B., Mahmood, H. S., Quraishi, M. Z., Hoogmoed, W. B., Mouazen, A. M., and van Henten, E. J. (2012) Sensing soil properties in the laboratory, in situ, and on-line. A review. Adv. Agron. 114: 155-223.

29. Wang, D., Chakraborty, S., Weindorf, D. C., Li, B., Sharma, A., Paul, S., Ali, N., Ali, M. N., and Ali, N. (2015) Synthesized use of VisNIR DRS and PXRF for soil characterization: Total carbon and total nitrogen. Geoderma 243-244: 157-167.

30. O'Rourke, S. M., Minasny, B., Holden, N. M., and McBratney, A. B. (2016) Synergistic Use of Vis-NIR, MIR, and XRF Spectroscopy for the Determination of Soil Geochemistry. Soil Sci. Soc. Am. J. 80 (4): 888-899.

31. Hodson, M. E. (2004) Heavy metals_-geochemical bogey men? Environ. Pollut. 129 (3): $341-343$.

32. Tsadilas, C. D. (2011) Dynamics and Bioavailability of Heavy Metals in the Rootzone. In Selim, M., Ed., CRC Press, Taylor and Francis Group, p 271.

33. Shaheen, S. M., Tsadilas, C. D., and Rinklebe, J. (2013) A review of the distribution coefficients of trace elements in soils: Influence of sorption system, element characteristics, and soil colloidal properties. Adv. Colloid Interface Sci. 201-202: 4356.

34. Pourret, O., and Bollinger, J.-C. (2018) "Heavy metal" - What to do now: To use or not to use? Sci. Total Environ. 610-611: 419-420.

35. Chapman, P. M. (2012) "Heavy metal"-cacophony, not symphony. Integr. Environ. Assess. Manag. 8 (2): 216-216.

36. Duffus. (2002) 'Heavy metals' a meaningless term? (IUPAC Technical Report). Pure Appl. Chem. 74 (5): 793-807.

37. Kabata-Pendias, A. (2011) Trace elements in Soils and Plants. CRC Press.

38. Janusa, M. A., and Beck, J. N. (2002) Recent applications of flame atomic absorption spectrometry to environmental measurements. Appl. Spectrosc. Rev. 37 (2): 137-186.

39. Sneddon, J., and Vincent, M. D. (2008) ICP-OES and ICP-MS for the determination of metals: Application to oysters. Anal. Lett. 41 (8): 1291-1303.

40. Sneddon, J., Hardaway, C., Bobbadi, K. K., and Reddy, A. K. (2006) Sample preparation of solid samples for metal determination by atomic spectroscopy - An overview and selected recent applications. Appl. Spectrosc. Rev. 41 (1): 1-14.

41. Hou, X., He, Y., and Jones, B. T. (2004) Recent Advances in Portable X- Ray Fluorescence Spectrometry. Appl. Spectrosc. Rev. 39 (1): 1-25. 
42. Kaniu, M. I., Angeyo, K. H., Mwala, A. K., and Mangala, M. J. (2012) Direct rapid analysis of trace bioavailable soil macronutrients by chemometrics-assisted energy dispersive X-ray fluorescence and scattering spectrometry. Anal. Chim. Acta 729: 2125 .

43. Gates, W. P. (2006) Chapter 12.3 X-ray Absorption Spectroscopy. Dev. Clay Sci. 1 (C): 789-864.

44. Bosco, G. L. (2013) Development and application of portable, hand-held X-ray fluorescence spectrometers. TrAC Trends Anal. Chem. 45: 121-134.

45. Kalnicky, D. J., and Singhvi, R. (2001) Field portable XRF analysis of environmental samples. J. Hazard. Mater. 83 (1-2): 93-122.

46. Gilfrich, J. V. (1990) New horizons in x-ray fluorescence analysis. X-Ray Spectrom. 19 (2): 45-51.

47. Potts, P. J., Williams-Thorpe, O., and Webb, P. C. (1997) The Bulk Analysis of Silicate Rocks by Portable X-Ray Fluorescence: Effect of Sample Mineralogy in Relation to the Size of the Excited Volume. Geostand. Geoanalytical Res. 21 (1): 2941.

48. dos Anjos, M., Lopes, R., de Jesus, E. F., Assis, J., Cesareo, R., and Barradas, C. A. (2000) Quantitative analysis of metals in soil using X-ray fluorescence. Spectrochim. Acta Part B At. Spectrosc. 55 (7): 1189-1194.

49. Kaminski, M. D., and Landsberger, S. (2000) Heavy Metals in Urban Soils of East St. Louis, IL, Part I: Total Concentration of Heavy Metals in Soils. J. Air Waste Manag. Assoc. J. J. Air Waste Manag. Assoc. J. Air Waste Manag. Assoc. J. Air Waste Manag. Assoc 509 (50): 1096-2247.

50. Bueno, P. C., Bellido, E., Rubí, J. A. M. M., and Ballesta, R. J. (2009) Concentration and spatial variability of mercury and other heavy metals in surface soil samples of periurban waste mine tailing along a transect in the Almadén mining district (Spain). Environ. Geol. 56 (5): 815-824.

51. Krishna, A. K., Mohan, K. R., Murthy, N. N., Periasamy, V., Bipinkumar, G., Manohar, K., and Rao, S. S. (2013) Assessment of heavy metal contamination in soils around chromite mining areas, Nuggihalli, Karnataka, India. Environ. Earth Sci. 70 (2): 699-708.

52. Machender, G., Dhakate, R., Prasanna, L., and Govil, P. K. (2011) Assessment of heavy metal contamination in soils around Balanagar industrial area, Hyderabad, India. Environ. Earth Sci. 63 (5): 945-953.

53. Chen, X., Lu, X., and Yang, G. (2012) Sources identification of heavy metals in urban topsoil from inside the Xi'an Second Ringroad, NW China using multivariate statistical methods. CATENA 98: 73-78.

54. West, M., Ellis, A. T., Potts, P. J., Streli, C., Vanhoof, C., Wegrzynek, D., and Wobrauschek, P. (2013) 2013 Atomic spectrometry update-A review of advances in X-ray fluorescence spectrometry. J. Anal. At. Spectrom. 28 (10): 1544. 
55. Parsons, C., Margui Grabulosa, E., Pili, E., Floor, G. H., Roman-Ross, G., and Charlet, L. (2013) Quantification of trace arsenic in soils by field-portable X-ray fluorescence spectrometry: Considerations for sample preparation and measurement conditions. $J$. Hazard. Mater. 262: 1213-1222.

56. Turner, A., Poon, H., Taylor, A., and Brown, M. T. (2017) In situ determination of trace elements in Fucus spp. by field-portable-XRF. Sci. Total Environ. 593-594: 227235 .

57. Weindorf, D. C., Zhu, Y., McDaniel, P., Valerio, M., Lynn, L., Michaelson, G., Clark, M., and Ping, C. L. (2012) Characterizing soils via portable x-ray fluorescence spectrometer: 2. Spodic and Albic horizons. Geoderma 189-190: 268-277.

58. Kinney, A., Mack, J., and McKenna, G. (2002) Using a Field Analytical Approach to Accelerate Site Assessments. In Innovative Approaches to the On-Site Assessment and Remediation of Contaminated Sites, Reible, D., Demnerova, K. (Eds., Springer Netherlands: Dordrecht, pp 1-30.

59. Melquiades, F. L., and Appoloni, C. R. (2004) Application of XRF and field portable XRF for environmental analysis. J. Radioanal. Nucl. Chem. 262 (2): 533-541.

60. Block, C. N., Shibata, T., Solo-Gabriele, H. M., and Townsend, T. G. (2007) Use of handheld X-ray fluorescence spectrometry units for identification of arsenic in treated wood. Environ. Pollut. 148 (2): 627-33.

61. Jang, M. (2010) Application of portable X-ray fluorescence (pXRF) for heavy metal analysis of soils in crop fields near abandoned mine sites. Environ. Geochem. Health 32 (3): 207-216.

62. Radu, T., and Diamond, D. (2009) Comparison of soil pollution concentrations determined using AAS and portable XRF techniques. J. Hazard. Mater. 171 (1-3): $1168-1171$.

63. Kilbride, C., Poole, J., and Hutchings, T. R. (2006) A comparison of $\mathrm{Cu}, \mathrm{Pb}, \mathrm{As}, \mathrm{Cd}$, $\mathrm{Zn}, \mathrm{Fe}, \mathrm{Ni}$ and $\mathrm{Mn}$ determined by acid extraction/ICP-OES and ex situ field portable X-ray fluorescence analyses. Environ. Pollut. 143 (1): 16-23.

64. Frahm, E., and Doonan, R. C. P. (2013) The technological versus methodological revolution of portable XRF in archaeology. J. Archaeol. Sci. 40 (2): 1425-1434.

65. Reynolds, M., and Langridge, P. (2016) Physiological breeding. Curr. Opin. Plant Biol. 31: 162-71.

66. Simandl, G. J., Stone, R. S., Paradis, S., Fajber, R., Reid, H. M., and Grattan, K. (2014) An assessment of a handheld X-ray fluorescence instrument for use in exploration and development with an emphasis on REEs and related specialty metals. Miner. Depos. 49 (8): 999-1012.

67. McLaren, T. I., Guppy, C. N., Tighe, M. K., Forster, N., Grave, P., Lisle, L. M., and Bennett, J. W. (2012) Rapid, Nondestructive Total Elemental Analysis of Vertisol Soils using Portable X-ray Fluorescence. Soil Sci. Soc. Am. J. 76 (4):1436-1445.

68. McWhirt, A., Weindorf, D. C., and Zhu, Y. (2012) Rapid analysis of elemental 
concentrations in compost via portable x-ray fluorescence spectrometry. Compost Sci. Util. 20 (3): 185-193.

69. Weindorf, D. C., Bakr, N., Zhu, Y., Mcwhirt, A., Ping, C. L., Michaelson, G., Nelson, C., Shook, K., and Nuss, S. (2014) Influence of Ice on Soil Elemental Characterization via Portable X-Ray Fluorescence Spectrometry. Pedosphere 24 (1): 1-12.

70. Binstock D.A., Gutknecht, W.F., M. A. C. (2009) Lead in soil, an examination of paired XRF analysis performed in the field and laboratory ICP-AES results. Int. J. soil Sediment Water 2 (2).

71. Figueroa-Cisterna, J., Bagur-González, M. G., Morales-Ruano, S., Carrillo-Rosúa, J., and Martín-Peinado, F. (2011) The use of a combined portable X ray fluorescence and multivariate statistical methods to assess a validated macroscopic rock samples classification in an ore exploration survey. Talanta 85 (5): 2307-2315.

72. Towett, E. K., Shepherd, K. D., and Cadisch, G. (2013) Quantification of total element concentrations in soils using total X-ray fluorescence spectroscopy (TXRF). Sci. Total Environ. 463-464: 374-388.

73. Moros, J., Gredilla, A., Fdez-Ortiz de Vallejuelo, S., de Diego, A., Madariaga, J. M., Garrigues, S., and de la Guardia, M. (2010) Partial least squares X-ray fluorescence determination of trace elements in sediments from the estuary of Nerbioi-Ibaizabal River. Talanta 82 (4): 1254-1260.

74. Kaniu, M. I. I., Angeyo, K. H. H., Mwala, A. K. K., and Mwangi, F. K. K. (2012) Talanta Energy dispersive X-ray fluorescence and scattering assessment of soil quality via partial least squares and artificial neural networks analytical modeling approaches. Talanta 98: 236-240.

75. Hu, B., Chen, S., Hu, J., Xia, F., Xu, J., Li, Y., and Shi, Z. (2017) Application of portable XRF and VNIR sensors for rapid assessment of soil heavy metal pollution. PLoS One 12 (2): 1-13.

76. El Haddad, J., Canioni, L., and Bousquet, B. (2014) Good practices in LIBS analysis: Review and advices. Spectrochim. Acta - Part B At. Spectrosc. 101: 171-182.

77. Cremers, D. A., and Chinni, R. C. (2009) Laser-induced breakdown spectroscopycapabilities and limitations. Appl. Spectrosc. Rev. 44 (6): 457-506.

78. Harmon, R. S., and Russo, R. E. (2014) Laser-Induced Breakdown Spectroscopy. In Treatise on Geochemistry, Elsevier, pp 245-272.

79. van der Mullen, J. A. M. (1990) Excitation equilibria in plasmas; a classification. Phys. Rep. 191 (2-3): 109-220.

80. Anabitarte, F., Cobo, A., and Lopez-Higuera, J. M. (2012) Laser-Induced Breakdown Spectroscopy: Fundamentals, Applications, and Challenges. ISRN Spectrosc. 2012: 112.

81. Russo, R. E., Mao, X. L., Liu, C., and Gonzalez, J. (2004) Laser assisted plasma spectrochemistry: Laser ablation. J. Anal. At. Spectrom. 19 (9), 1084. doi:10.1039/b403368j. 
82. Kim, G., Kwak, J., Kim, K. R., Lee, H., Kim, K. W., Yang, H., and Park, K. (2013) Rapid detection of soils contaminated with heavy metals and oils by laser induced breakdown spectroscopy (LIBS). J. Hazard. Mater. 263: 754-760.

83. Dell'Aglio, M., Gaudiuso, R., Senesi, G. S., De Giacomo, A., Zaccone, C., Miano, T. M., and De Pascale, O. (2011) Monitoring of $\mathrm{Cr}, \mathrm{Cu}, \mathrm{Pb}, \mathrm{v}$ and $\mathrm{Zn}$ in polluted soils by laser induced breakdown spectroscopy (LIBS). J. Environ. Monit. 13 (5): 1422-1426.

84. Bublitz, J., Dölle, C., Schade, W., Hartmann, A., and Horn, R. (2001) Laser-induced breakdown spectroscopy for soil diagnostics. Eur. J. Soil Sci. 52 (2): 305-312.

85. Senesi, G. S., and Senesi, N. (2016) Laser-induced breakdown spectroscopy (LIBS) to measure quantitatively soil carbon with emphasis on soil organic carbon. A review. Anal. Chim. Acta 938: 7-17.

86. Capitelli, F., Colao, F., Provenzano, M. R., Fantoni, R., Brunetti, G., and Senesi, N. (2002) Determination of heavy metals in soils by Laser Induced Breakdown Spectroscopy. Geoderma 106 (1-2): 45-62.

87. Senesi, G. S., Dell'Aglio, M., Gaudiuso, R., De Giacomo, A., Zaccone, C., De Pascale, O., Miano, T. M., and Capitelli, M. (2009) Heavy metal concentrations in soils as determined by laser-induced breakdown spectroscopy (LIBS), with special emphasis on chromium. Environ. Res. 109 (4): 413-420.

88. Ismaël, A., Bousquet, B., Michel-Le Pierrès, K., Travaillé, G., Canioni, L., and Roy, S. (2011) In situ semi-quantitative analysis of polluted soils by laser-induced breakdown spectroscopy (LIBS). Appl. Spectrosc. 65 (5): 467-473.

89. Gómez-Nubla, L., Aramendia, J., Fdez-Ortiz de Vallejuelo, S., and Madariaga, J. M. (2018) Analytical methodology to elemental quantification of weathered terrestrial analogues to meteorites using a portable Laser-Induced Breakdown Spectroscopy (LIBS) instrument and Partial Least Squares (PLS) as multivariate calibration technique. Microchem. J. 137: 392-401.

90. Hahn, D. W., and Omenetto, N. (2012) Laser-induced breakdown spectroscopy (LIBS), part II: Review of instrumental and methodological approaches to material analysis and applications to different fields. Appl. Spectrosc. 66 (4): 347-419.

91. Jurado-López, A., and Luque De Castro, M. D. (2003) Chemometric approach to laserinduced breakdown analysis of gold alloys. Appl. Spectrosc. 57 (3): 349-352.

92. Galbács, G., Gornushkin, I. B., Smith, B. W., and Winefordner, J. D. (2001) Semiquantitative analysis of binary alloys using laser-induced breakdown spectroscopy and a new calibration approach based on linear correlation. Spectrochim. Acta - Part B At. Spectrosc. 56 (7): 1159-1173.

93. Gornushkin, I. B., Smith, B. W., Nasajpour, H., and Winefordner, J. D. (1999) Identification of solid materials by correlation analysis using a microscopic laserinduced plasma spectrometer. Anal. Chem. 71 (22): 5157-5164.

94. Liu, X., Liu, F., Huang, W., Peng, J., Shen, T., and He, Y. (2018) Quantitative determination of $\mathrm{Cd}$ in soil using laser-induced breakdown spectroscopy in air and ar conditions. Molecules 23 (10): 2492. 
95. Stenberg, B., Viscarra Rossel, R. A., Mouazen, A. M., and Wetterlind, J. (2010) Visible and Near Infrared Spectroscopy in Soil Science. In Advances in Agronomy, Academic Press, pp 163-215.

96. Janik, L. J., Skjemstad, J. O., Merry, R. H., and Skjemstad, J. O. (1998) Can mid infrared diffuse reflectance analysis replace soil extractions? Aust. J. Exp. Agric. 38 (7): 681-696

97. Soriano-Disla, J. M., Janik, L. J., Viscarra Rossel, R. A., MacDonald, L. M., and McLaughlin, M. J. (2014) The performance of visible, near-, and mid-infrared reflectance spectroscopy for prediction of soil physical, chemical, and biological properties. Appl. Spectrosc. Rev. 49 (2): 139-186.

98. Mouazen, A. M. M., Kuang, B., De Baerdemaeker, J., Ramon, H., Baerdemaeker, J. De, Ramon, H., De Baerdemaeker, J., Ramon, H., Baerdemaeker, J. De, Ramon, H., De Baerdemaeker, J., and Ramon, H. (2010) Comparison among principal component, partial least squares and back propagation neural network analyses for accuracy of measurement of selected soil properties with visible and near infrared spectroscopy. Geoderma 158 (1-2): 23-31.

99. Li-Chan, E. C. Y., Li- Chan, and C.Y., E. (2010) Introduction to Vibrational Spectroscopy in Food Science. In Handbook of Vibrational Spectroscopy, Li-Chan, E.C.Y., Ed., John Wiley \& Sons, Ltd: Chichester, UK.

100. McClure, W. F. (2003) 204 Years of near Infrared Technology: 1800-2003. J. Near Infrared Spectrosc. 11 (6): 487-518.

101. Kooistra, L., Wehrens, R., Buydens, L. M. C., Leuven, R. S. E. W., and Nienhuis, P. H. (2001) Possibilities of soil spectroscopy for the classification of contaminated areas in river floodplains. Anal. Chim. Acta 446: 97-105.

102. Siebielec, G., McCarty, G. W., Stuczynski, T. I., and Reeves, J. B. (2004) Near- and mid-infrared diffuse reflectance spectroscopy for measuring soil metal content. $J$. Environ. Qual. 33 (6): 2056-69.

103. Wu, Y., Chen, J., Wu, X., Tian, Q., Ji, J., and Qin, Z. (2005) Possibilities of reflectance spectroscopy for the assessment of contaminant elements in suburban soils. Appl. Geochemistry 20 (6): 1051-1059.

104. Chodak, M., Niklińska, M., and Beese, F. (2007) Near-infrared spectroscopy for analysis of chemical and microbiological properties of forest soil organic horizons in a heavy-metal-polluted area. Biol. Fertil. Soils 44 (1): 171-180.

105. Zheng, G. H., Zhou, S. L., and Wu, S. H. (2011) Prediction of As in Soil with Reflectance Spectroscopy. Spectrosc. Spectr. Anal. 31 (1): 173-176.

106. Choe, E., Kim, K.-W., Bang, S., Yoon, I.-H., and Lee, K.-Y. (2009) Qualitative analysis and mapping of heavy metals in an abandoned $\mathrm{Au}-\mathrm{Ag}$ mine area using NIR spectroscopy. Environ. Geol. 58 (3): 477-482.

107. Wang, J., Cui, L., Gao, W., Shi, T., Chen, Y., and Gao, Y. (2014) Prediction of low heavy metal concentrations in agricultural soils using visible and near-infrared reflectance spectroscopy. Geoderma 216: 1-9. 
108. Gholizadeh, A., Borůvka, L., Vašát, R., Saberioon, M., Klement, A., Kratina, J., Tejnecký, V., and Drábek, O. (2015) Estimation of Potentially Toxic Elements Contamination in Anthropogenic Soils on a Brown Coal Mining Dumpsite by Reflectance Spectroscopy: A Case Study. PLoS One 10 (2): e0117457.

109. Wu, C.-Y., Jacobson, A. R., Laba, M., Kim, B., and Baveye, P. C. (2010) Surrogate Correlations and Near-Infrared Diffuse Reflectance Sensing of Trace Metal Content in Soils. Water, Air, Soil Pollut. 209 (1-4): 377-390.

110. Sut, M., Fischer, T., Repmann, F., Raab, T., and Dimitrova, T. (2012) Feasibility of Field Portable Near Infrared (NIR) Spectroscopy to Determine Cyanide Concentrations in Soil. Water, Air, Soil Pollut. 223 (8): 5495-5504.

111. Pandit, C. M., Filippelli, G. M., and Li, L. (2010) Estimation of heavy-metal contamination in soil using reflectance spectroscopy and partial least-squares regression. Int. J. Remote Sens. 31 (15): 4111-4123.

112. Wu, Y., Chen, J., Ji, J., Gong, P., Liao, Q., Tian, Q., and Ma, H. (2007) A Mechanism Study of Reflectance Spectroscopy for Investigating Heavy Metals in Soils. Soil Sci. Soc. Am. J. 71 (3): 918-926.

113. Kooistra, L., Wehrens, R., Leuven, R. S. E., and Buydens, L. M. (2001) Possibilities of visible-near-infrared spectroscopy for the assessment of soil contamination in river floodplains. Anal. Chim. Acta 446 (1-2): 97-105.

114. Bellon-Maurel, V., and McBratney, A. (2011) Near-infrared (NIR) and mid-infrared (MIR) spectroscopic techniques for assessing the amount of carbon stock in soils Critical review and research perspectives. Soil Biol. Biochem. 43 (7): 1398-1410.

115. Rossel, R. A. V., and Behrens, T. (2010) Using data mining to model and interpret soil diffuse reflectance spectra. Geoderma 158 (1-2): 46-54.

116. Reeves, J. B. (2010) Near- versus mid-infrared diffuse reflectance spectroscopy for soil analysis emphasizing carbon and laboratory versus on-site analysis: Where are we and what needs to be done? Geoderma 158 (1-2): 3-14.

117. Nakamoto, K. (2008) Infrared and Raman Spectra of Inorganic and Coordination Compounds. John Wiley \& Sons, Inc.: Hoboken, NJ, USA.

118. Reeves, J. B., McCarty, G. W., and Reeves, V. B. (2001) Mid-infrared diffuse reflectance spectroscopy for the quantitative analysis of agricultural soils. J. Agric. Food Chem. 49 (2): 766-772.

119. McCarty, G. W., and Reeves, J. B. (2006) No Title. Soil Sci. 171 (2): 94-102.

120. Araújo, S. R., Wetterlind, J., Demattê, J. A. M., and Stenberg, B. (2014) Improving the prediction performance of a large tropical vis-NIR spectroscopic soil library from Brazil by clustering into smaller subsets or use of data mining calibration techniques. Eur. J. Soil Sci. 65 (5): 718-729.

121. Wu, Y. Z., Chen, J., Ji, J. F., Tian, Q. J., and Wu, X. M. (2005) Feasibility of reflectance spectroscopy for the assessment of soil mercury contamination. Environ. Sci. Technol. 39 (3): 873-878. 
122. Choe, E., van der Meer, F., van Ruitenbeek, F., van der Werff, H., de Smeth, B., and Kim, K.-W. (2008) Mapping of heavy metal pollution in stream sediments using combined geochemistry, field spectroscopy, and hyperspectral remote sensing: A case study of the Rodalquilar mining area, SE Spain. Remote Sens. Environ. 112 (7): 32223233 .

123. REN, H.-Y., ZHUANG, D.-F., SINGH, A. N., PAN, J.-J., QIU, D.-S., and SHI, R.-H. (2009) Estimation of As and $\mathrm{Cu}$ Contamination in Agricultural Soils Around a Mining Area by Reflectance Spectroscopy: A Case Study. Pedosphere 19 (6): 719-726.

124. Vohland, M., Bossung, C., and Fründ, H. C. (2009) A spectroscopic approach to assess trace - heavy metal contents in contaminated floodplain soils via spectrally active soil components. J. Plant Nutr. Soil Sci. 172 (2): 201-209.

125. Liu, Y., Li, W., Wu, G., and Xu, X. (2011) Feasibility of estimating heavy metal contaminations in floodplain soils using laboratory-based hyperspectral data-A case study along Le'an River, China. Geo-spatial Inf. Sci. 14 (1): 10-16.

126. Wu, Y., Zhang, X., Liao, Q., and Ji, J. (2011) Can Contaminant Elements in Soils Be Assessed by Remote Sensing Technology. Soil Sci. 176 (4): 196-205.

127. Song, Y., Li, F., Yang, Z., Ayoko, G. A., Frost, R. L., and Ji, J. (2012) Diffuse reflectance spectroscopy for monitoring potentially toxic elements in the agricultural soils of Changjiang River Delta, China. Appl. Clay Sci. 64: 75-83.

128. Minasny, B., Tranter, G., McBratney, A. B., Brough, D. M., and Murphy, B. W. (2009) Regional transferability of mid-infrared diffuse reflectance spectroscopic prediction for soil chemical properties. Geoderma 153 (1-2): 155-162.

129. Dong, Y. W., Yang, S. Q., Xu, C. Y., Li, Y. Z., Bai, W., Fan, Z. N., Wang, Y. N., and Li, Q. Z. (2011) Determination of Soil Parameters in Apple-Growing Regions by Near- and Mid-Infrared Spectroscopy. Pedosphere 21 (5): 591-602.

130. Soriano-Disla, J. M. M., Janik, L., McLaughlin, M. J. J., Forrester, S., Kirby, J. K., Reimann, C., K. Kirby, J., and Reimann, C. (2013) Prediction of the concentration of chemical elements extracted by aqua regia in agricultural and grazing European soils using diffuse reflectance mid-infrared spectroscopy. Appl. Geochemistry 39: 33-42.

131. Camargo, L. A., Marques, J., Barrón, V., Alleoni, L. R. F., Pereira, G. T., Teixeira, D. D. B., and Bahia, A. S. R. de S. (2018) Predicting potentially toxic elements in tropical soils from iron oxides, magnetic susceptibility and diffuse reflectance spectra. Catena 165: 503-515.

132. Li, F., Lu, A., and Wang, J. (2017) Modeling of chromium, copper, zinc, arsenic and lead using portable X-ray fluorescence spectrometer based on discrete wavelet transform. Int. J. Environ. Res. Public Health 14 (10): 1163.

133. Caporale, A. G., Adamo, P., Capozzi, F., Langella, G., Terribile, F., and Vingiani, S. (2018) Monitoring metal pollution in soils using portable-XRF and conventional laboratory-based techniques: Evaluation of the performance and limitations according to metal properties and sources. Sci. Total Environ. 643: 516-526.

134. Capitelli, F., Colao, F., Provenzano, M., Fantoni, R., Brunetti, G., and Senesi, N. 
(2002) Determination of heavy metals in soils by Laser Induced Breakdown Spectroscopy. Geoderma 106 (1-2): 45-62.

135. Senesi, G. S., Dell'Aglio, M., Gaudiuso, R., De Giacomo, A., Zaccone, C., De Pascale, O., Miano, T. M., and Capitelli, M. (2009) Heavy metal concentrations in soils as determined by laser-induced breakdown spectroscopy (LIBS), with special emphasis on chromium. Environ. Res. 109 (4): 413-420.

136. Grunwald, S., Vasques, G. M., and Rivero, R. G. (2016) Fusion of soil and remote sensing data to model soil properties. Adv. Agron. 131: 1-109.

137. Mouazen, A. M., Alhwaimel, S. A., Kuang, B., and Waine, T. (2014) Multiple on-line soil sensors and data fusion approach for delineation of water holding capacity zones for site specific irrigation. Soil Tillage Res. 143: 95-105.

138. Pantazi, X. E., Moshou, D., Mouazen, A. M., Alexandridis, T., and Kuang, B. (2015) Data Fusion of Proximal Soil Sensing and Remote Crop Sensing for the Delineation of Management Zones in Arable Crop Precision Farming. The 7th International Conference on Information and Communication Technologies in Agriculture, Food and Environment (HAICTA 2015), kavala - Greece.

139. Castrignanò, A., Wong, M. T. F. F., Stelluti, M., Benedetto, D. De, Sollitto, D., De Benedetto, D., Sollitto, D., Benedetto, D. De, Sollitto, D., De Benedetto, D., Sollitto, D., Benedetto, D. De, and Sollitto, D. (2012) Use of EMI, gamma-ray emission and GPS height as multi-sensor data for soil characterisation. Geoderma 175-176: 78-89.

140. Mahmood, H. S., Hoogmoed, W. B., and Henten, E. J. Van. (2012) Sensor data fusion to predict multiple soil properties. (August): 628-645.

141. Hoegh, A., and Leman, S. (2018) Correlated model fusion. Appl. Stoch. Model. Bus. Ind. 34 (1): 31-43.

142. Chakraborty, S., Weindorf, D. C., Li, B., Abdalsatar, A., Aldabaa, A., Kumar, R., Paul, S., and Ali, N. (2015) Science of the Total Environment Development of a hybrid proximal sensing method for rapid identi fi cation of petroleum contaminated soils. Sci. Total Environ. 514: 399-408.

143. Towett, E. K., Shepherd, K. D., Sila, A., Aynekulu, E., and Cadisch, G. (2015) MidInfrared and Total X-Ray Fluorescence Spectroscopy Complementarity for Assessment of Soil Properties. Soil Sci. Soc. Am. J. 79 (5): 1375.

144. Rojas, R., Feyen, L., and Dassargues, A. (2008) Conceptual model uncertainty in groundwater modeling: Combining generalized likelihood uncertainty estimation and Bayesian model averaging. Water Resour. Res. 44, W12418, doi:10.1029/2008WR006908.

145. Ge, Y., Morgan, C. L. S., and Ackerson, J. P. (2014) VisNIR spectra of dried ground soils predict properties of soils scanned moist and intact. Geoderma 221-222: 61-69.

146. Roudier, P., Hedley, C. B., Lobsey, C. R., Viscarra Rossel, R. A., and Leroux, C. (2017) Evaluation of two methods to eliminate the effect of water from soil vis-NIR spectra for predictions of organic carbon. Geoderma 296: 98-107. 
147. Kuang, B., Mahmood, H. S., Quraishi, M. Z., Hoogmoed, W. B., Mouazen, A. M., and van Henten, E. J. (2012) Sensing Soil Properties in the Laboratory, In Situ, and OnLine. Adv. Agron. 114: 155-223.

148. Nawar, S., and Mouazen, A. M. (2017) Predictive performance of mobile vis-near infrared spectroscopy for key soil properties at different geographical scales by using spiking and data mining techniques. CATENA 151: 118-129.

149. Okparanma, R. N., Coulon, F., Mayr, T., and Mouazen, A. M. (2014) Mapping polycyclic aromatic hydrocarbon and total toxicity equivalent soil concentrations by visible and near-infrared spectroscopy. Environ. Pollut. 192: 162-170.

150. Suh, J., Lee, H., Choi, Y., Suh, J., Lee, H., and Choi, Y. (2016) A Rapid, Accurate, and Efficient Method to Map Heavy Metal-Contaminated Soils of Abandoned Mine Sites Using Converted Portable XRF Data and GIS. Int. J. Environ. Res. Public Health 13 (12): 1191. doi:10.3390/ijerph13121191

151. Carr, R., Zhang, C., Moles, N., and Harder, M. (2008) Identification and mapping of heavy metal pollution in soils of a sports ground in Galway City, Ireland, using a portable XRF analyser and GIS. Environ. Geochem. Health 30 (1): 45-52.

152. Gholizadeh, A., Saberioon, M., Ben-Dor, E., and Borůvka, L. (2018) Monitoring of selected soil contaminants using proximal and remote sensing techniques: Background, state-of-the-art and future perspectives. Crit. Rev. Environ. Sci. Technol. 48 (3): 243278.

153. Shi, T., Guo, L., Chen, Y., Wang, W., Shi, Z., Li, Q., and Wu, G. (2018) Proximal and remote sensing techniques for mapping of soil contamination with heavy metals. Appl. Spectrosc. Rev. 53 (10): 783-805.

154. Weindorf, D. C., and Chakraborty, S. (2016) Portable X-ray Fluorescence Spectrometry Analysis of Soils. Methods Soil Anal. 1 (1). doi:10.2136/methodssoil.2015.0033.

155. Soriano-Disla, J. M., Janik, L. J., and McLaughlin, M. J. (2018) Assessment of cyanide contamination in soils with a handheld mid-infrared spectrometer. Talanta 178: 400409. 
1 Table 1 Summary of case studies for estimation of potentially toxic elements (PTEs) concentrations in soils using visible and near-infrared spectroscopy (Vis-NIRS), mid-

2 infrared (MIRS), and X-ray fluorescence spectroscopy (XRFS), and laser-induced breakdown spectroscopy (LIBS) in soil matrices from different regions over the world.

3

\begin{tabular}{|c|c|c|c|c|c|c|c|c|c|c|}
\hline Elements & Country & $\begin{array}{c}\text { Samples } \\
\text { No }\end{array}$ & $\begin{array}{c}\text { Spectral } \\
\text { range } \\
(\mathbf{n m})\end{array}$ & $\begin{array}{c}\text { Pre- } \\
\text { processing }\end{array}$ & $\begin{array}{c}\text { Range } \\
\left(\mathbf{m g ~ k g}^{-1}\right)\end{array}$ & $\begin{array}{c}\text { Regression } \\
\text { technique }\end{array}$ & $\mathbf{R}^{2}$ & RMSE & RPD & Reference \\
\hline \multicolumn{11}{|c|}{ Vis-NIRS } \\
\hline $\mathrm{Cd}$ & Netherlands & 69 & $400-2500$ & FD+ NM & - & PLSR & 0.88 & 0.72 & - & (113) \\
\hline $\mathrm{Zn}$ & & & & & - & & 0.90 & 112.52 & - & \\
\hline As & Spain & 214 & $350-2500$ & $\mathrm{AB}+\mathrm{FD}$ & $7-442$ & ANN, MLR & $0.85,0.83$ & $\mathrm{SEP}=0.007-0.007$ & $3.28,3.83$ & (7) \\
\hline $\mathrm{Cd}$ & & & & & $0.05-14.8$ & & $0.49,0.51$ & $0.085,0.07$ & $0.96,1.23$ & \\
\hline $\mathrm{Cu}$ & & & & & $17.5-521$ & & $0.44,0.54$ & $0.09,0.085$ & $0.84,1.23$ & \\
\hline $\mathrm{Hg}$ & & & & & $0.01-13.9$ & & $0.92,0.95$ & $0.033,0.027$ & $4.30,5.77$ & \\
\hline $\mathrm{Sb}$ & & & & & $196-3362$ & & $0.92,0.92$ & $0.028,0.033$ & $4.55,4.66$ & \\
\hline $\mathrm{Pb}$ & & & & & $17.5-3331.5$ & & $0.94,0.94$ & $0.028,0.031$ & $5.89,5.30$ & \\
\hline $\mathrm{Zn}$ & & & & & $94.0-3887.0$ & & $0.22,0.23$ & $0.08,0.08$ & $0.51,0.59$ & \\
\hline $\mathrm{Fe}$ & Poland & 70 & $400-2498$ & MSC & $0-160.0$ & PLSR & 0.87 & RMSD $=9.2$ & & (102) \\
\hline $\mathrm{Cd}$ & & & & & $0-38.0$ & & 0.54 & 5.13 & - & \\
\hline $\mathrm{Cu}$ & & & & & $3.0-78.0$ & & 0.61 & 10.3 & - & \\
\hline $\mathrm{Pb}$ & & & & & $0.0-6800$ & & 0.45 & 839.0 & - & \\
\hline $\mathrm{Ni}$ & & & & & $3.0-77.0$ & & 0.84 & 6.21 & - & \\
\hline $\mathrm{Zn}$ & & & & & $0-4500$ & & 0.67 & 526.0 & - & \\
\hline $\mathrm{Hg}$ & China & 105 & $380-2500$ & AB, K-M & $0.04-1.26$ & PCR & 0.71 & 0.15 & - & (121) \\
\hline As & China & 120 & $900-2500$ & MSC & $5.57-47.07$ & PLSR & 0.65 & 1.65 & - & (103) \\
\hline $\mathrm{Cr}$ & & & & & & & 0.76 & 5.60 & - & \\
\hline
\end{tabular}




\begin{tabular}{|c|c|c|c|c|c|c|c|c|c|c|}
\hline $\mathrm{Cu}$ & & & & & $9.60-73.40$ & & 0.62 & 7.61 & - & \\
\hline $\mathrm{Hg}$ & & & & & $0.04-1.26$ & & 0.59 & 0.117 & - & \\
\hline $\mathrm{Ni}$ & & & & & $10.60-57.50$ & & 0.86 & 2.21 & - & \\
\hline $\mathrm{Pb}$ & & & & & $22.30-208.00$ & & 0.66 & 4.97 & - & \\
\hline $\mathrm{Zn}$ & & & & & $43.90-625.00$ & & 0.62 & 13.6 & - & \\
\hline As & China & 61 & $380-2300$ & CR & $6.13-13.30$ & PLSR & 0.72 & 0.86 & 1.90 & (112) \\
\hline $\mathrm{Cd}$ & & & & & $0.22-0.54$ & & 0.20 & 0.05 & 1.23 & \\
\hline Co & & & & & $11.5-19.7$ & & 0.80 & 0.93 & 218.0 & \\
\hline $\mathrm{Cr}$ & & & & & $60.8-104.0$ & & 0.85 & 4.20 & 2.50 & \\
\hline $\mathrm{Cu}$ & & & & & $26.5-55.3$ & & 0.67 & 3.74 & 1.74 & \\
\hline $\mathrm{Ni}$ & & & & & $27.3-50.6$ & & 0.81 & 2.32 & 2.35 & \\
\hline $\mathrm{Pb}$ & & & & & $21.4-42.8$ & & 0.55 & 3.58 & 1.49 & \\
\hline $\mathrm{Zn}$ & & & & & $68.8-120.0$ & & 0.56 & 8.20 & 1.45 & \\
\hline As & Spain & 49 & $350-2500$ & $\mathrm{CR}+\mathrm{NM}$ & $292.2-826.9$ & SMLR, EMLR & $0.84,0.88$ & $0.12,0.11$ & $2.36,2.56$ & (122) \\
\hline $\mathrm{Pb}$ & & & & & $\begin{array}{l}1412.7- \\
18,811.3\end{array}$ & & $0.53,0.61$ & $0.38,0.37$ & $1.36,1.39$ & \\
\hline $\mathrm{Zn}$ & & & & & 200.9-728.1 & & $0.54,0.59$ & $0.22,0.23$ & $1.39,1.38$ & \\
\hline As & $\begin{array}{l}\text { South } \\
\text { Korea }\end{array}$ & 22 & $400-2400$ & $\mathrm{CR}$ & 52.4-1493.8 & SMLR, EMLR & $0.37,0.59$ & $\mathrm{SEP}=0.27,0.25$ &,-- & (106) \\
\hline $\mathrm{Cu}$ & & & & & 21.9-252.6S & & $0.24,0.81$ & $0.21,0.12$ &,-- & \\
\hline $\mathrm{Pb}$ & & & & & $56.8-152.5$ & &,- 0.27 &,- 0.15 &,-- & \\
\hline As & China & 33 & $350-2500$ & $\mathrm{FD}, \mathrm{CR}$ & $19.33-403.77$ & PLSR & 0.61 & 0.24 & & (123) \\
\hline $\mathrm{Cu}$ & & & & & $31.83-190.51$ & & 0.39 & 0.20 & & \\
\hline $\mathrm{Fe}$ & & & & & $28.14-64.20$ & & 0.43 & 0.12 & & \\
\hline $\mathrm{Cu}$ & Germany & 109 & $400-2500$ & MSC & $8-1823$ & & 0.75 & 151.4 & - & (124) \\
\hline $\mathrm{Pb}$ & & & & & $0-605$ & & 0.75 & 58.1 & - & \\
\hline
\end{tabular}




\begin{tabular}{|c|c|c|c|c|c|c|c|c|c|c|}
\hline $\mathrm{Zn}$ & & & & & $40-1322$ & & 0.81 & 117.5 & - & \\
\hline $\mathrm{Fe}$ & & & & & - & & 0.84 & 4960 & - & \\
\hline $\mathrm{Mn}$ & & & & & - & & 0.70 & 363.3 & - & \\
\hline $\mathrm{Pb}$ & USA & 24 & $350-2500$ & & $8-1823$ & & 0.74 & & - & (111) \\
\hline $\mathrm{Zn}$ & & & & & $0-605$ & & 0.76 & & - & \\
\hline $\mathrm{Cu}$ & & & & & $40-1322$ & & 0.81 & & - & \\
\hline $\mathrm{Cd}$ & & & & & - & & 0.42 & & - & \\
\hline $\mathrm{Mn}$ & & & & & - & & 0.80 & & - & \\
\hline $\mathrm{Cu}$ & & 30 & $350-2500$ & $\mathrm{AB}+\mathrm{FD}$ & $1.670-332.18$ & UR & 0.79 & 17.85 & - & $(125)$ \\
\hline $\mathrm{Pb}$ & & & & & $2.480-50.920$ & & 0.65 & 0.91 & - & \\
\hline $\mathrm{Zn}$ & & & & & $73.76-269.53$ & & 0.61 & 22.51 & - & \\
\hline $\mathrm{Zn}$ & & & & & $43.90-625.00$ & & 0.62 & 13.6 & - & \\
\hline $\mathrm{Ni}$ & & 120 & $380-2500$ & & - & PLSR, MARS & $0.75,0.93$ & $2.94,229$ & $1.99,2.56$ & (126) \\
\hline $\mathrm{Cr}$ & & & & & - & & $0.71,0.83$ & $5.54,4.29$ & $1.96,2.54$ & \\
\hline $\mathrm{Cu}$ & & & & & & & $0.55,0.77$ & $6.49,4.62$ & $1.49,2.09$ & \\
\hline As & & & & & & & $0.40,0.53$ & $1.14,1.00$ & $1.28,1.46$ & \\
\hline $\mathrm{Zn}$ & & & & & & & $0.48,0.68$ & $14.78,11.41$ & $1.37,1.78$ & \\
\hline $\mathrm{Pb}$ & & & & & & & $0.38,0.60$ & $5.92,4.67$ & $1.25,1.59$ & \\
\hline $\mathrm{Cd}$ & & & & & & & $0.69,0.80$ & $0.04,0.04$ & $2.45,2.45$ & \\
\hline As & & 122 & $350-2500$ & FD-UVN & $3.800-16.600$ & PLSR & 0.45 & 1.60 & 1.13 & (127) \\
\hline $\mathrm{Cd}$ & & & & Non & $0.081-1.441$ & & 0.30 & 0.16 & 0.97 & \\
\hline $\mathrm{Cr}$ & & & & Non & $30.990-113.90$ & & 0.98 & 19.46 & 1.01 & \\
\hline $\mathrm{Cu}$ & & & & Non & $9.100-55.500$ & & 0.92 & 5.45 & 1.54 & \\
\hline $\mathrm{Hg}$ & & & & FD-UVN & $0.030-0.330$ & & 0.83 & 0.048 & 1.23 & \\
\hline $\mathrm{Pb}$ & & & & UVN & $11.120-89.680$ & & 0.68 & 5.94 & 1.11 & \\
\hline
\end{tabular}




\begin{tabular}{|c|c|c|c|c|c|c|c|c|c|c|}
\hline & & & & & & MIRS & & & & \\
\hline $\mathrm{Fe}$ & \multirow[t]{6}{*}{ Poland } & \multirow[t]{6}{*}{70} & \multirow[t]{6}{*}{$\begin{array}{l}2500- \\
25000\end{array}$} & \multirow[t]{6}{*}{ MSC } & $0.1-160$ & PLSR & 0.97 & 4.10 & & (102) \\
\hline $\mathrm{Cd}$ & & & & & $0.1-35.0$ & PLSR & 0.94 & 1.82 & & \\
\hline $\mathrm{Cu}$ & & & & & $0.1-78.0$ & & 0.80 & 7.52 & & \\
\hline $\mathrm{Pb}$ & & & & & $0.1-6800$ & & 0.66 & 662 & & \\
\hline $\mathrm{Ni}$ & & & & & $0.5-75.0$ & & 0.98 & 1.88 & & \\
\hline $\mathrm{Zn}$ & & & & & $0.5-4500$ & & 0.96 & 191 & & \\
\hline $\mathrm{Cu}$ & \multirow[t]{4}{*}{ Australia } & \multirow[t]{4}{*}{49} & \multirow{4}{*}{$\begin{array}{l}2500- \\
25000\end{array}$} & & $0.01-7.2$ & Cubist & 0.14 & 0.65 & 1 & (128) \\
\hline $\mathrm{Fe}$ & & & & & $2.6-500$ & & 0.49 & 35.30 & 1.3 & \\
\hline $\mathrm{Mn}$ & & & & & $0.67-152$ & & 0.15 & 18.66 & 1 & \\
\hline $\mathrm{Zn}$ & & & & & $0.05-11$ & & 0.15 & 0.90 & 1 & \\
\hline As & \multirow[t]{5}{*}{ China } & \multirow[t]{5}{*}{111} & \multirow[t]{5}{*}{$\begin{array}{l}8000- \\
25000\end{array}$} & \multirow[t]{5}{*}{ SNV } & $3.73-16.51$ & PLSR & 0.92 & & 1.75 & (129) \\
\hline $\mathrm{Cu}$ & & & & & $8.70-196.7$ & & 0.80 & & 1.14 & \\
\hline $\mathrm{Zn}$ & & & & & $24.2-577.3$ & & 0.95 & & 1.56 & \\
\hline $\mathrm{Pb}$ & & & & & $7.10-767.0$ & & 0.56 & & 1.08 & \\
\hline $\mathrm{Cr}$ & & & & & $25.9-79.0$ & & 0.81 & & 1.36 & \\
\hline $\mathrm{Al}$ & \multirow{9}{*}{$\begin{array}{l}34 \\
\text { European } \\
\text { countries }\end{array}$} & \multirow[t]{9}{*}{3130} & \multirow{9}{*}{$\begin{array}{l}2500- \\
20000\end{array}$} & \multirow[t]{9}{*}{ De-trend } & $329-65090$ & PLSR & 0.83 & 0.13 & 2.4 & (130) \\
\hline $\mathrm{Fe}$ & & & & & 380-133926 & & 0.79 & 0.16 & 2.2 & \\
\hline $\mathrm{Ni}$ & & & & & $0.05-2475$ & & 0.77 & 0.24 & 2.1 & \\
\hline $\mathrm{Zn}$ & & & & & $1.50-1396$ & & 0.60 & 0.19 & 1.6 & \\
\hline $\mathrm{Cu}$ & & & & & $0.30-395$ & & 0.55 & 0.26 & 1.5 & \\
\hline $\mathrm{Mn}$ & & & & & $1.60-14969$ & & 0.54 & 0.27 & 1.5 & \\
\hline $\mathrm{Pb}$ & & & & & $1.60-1309$ & & 0.42 & 0.24 & 1.3 & \\
\hline $\mathrm{Se}$ & & & & & $0.08-6.8$ & & 0.40 & 0.19 & 1.3 & \\
\hline $\mathrm{Cd}$ & & & & & $0.005-7.5$ & & 0.40 & 0.29 & 1.3 & \\
\hline
\end{tabular}




\begin{tabular}{|c|c|c|c|c|c|c|c|c|c|c|}
\hline $\mathrm{Hg}$ & & & & & $0.002-3.1$ & & 0.33 & 0.29 & 1.2 & \\
\hline $\mathrm{Ag}$ & & & & & $0.001-3.9$ & & 0.30 & 0.3 & 1.2 & \\
\hline $\mathrm{Ba}$ & Brazil & 100 & $\begin{array}{l}2500- \\
16,666\end{array}$ & Absorbance & $14.3-65$ & PLSR & 0.91 & 16.1 & 3.4 & (131) \\
\hline Co & & & & & $2.1-3.7$ & & 0.90 & 0.6 & 3.2 & \\
\hline $\mathrm{Cu}$ & & & & & $1.5-3.8$ & & 0.69 & 0.3 & 1.8 & \\
\hline $\mathrm{Mn}$ & & & & & 118.9-204.4 & & 0.94 & 39.2 & 4.2 & \\
\hline $\mathrm{Ni}$ & & & & & $3.5-5.5$ & & 0.66 & 6.9 & 1.7 & \\
\hline $\mathrm{Zn}$ & & & & & $13.5-98.4$ & & 0.49 & 11.6 & 1.3 & \\
\hline $\mathrm{Al}$ & Germany & 100 & $\begin{array}{l}2500- \\
15,000\end{array}$ & $\mathrm{SNV}+\mathrm{FD}$ & $4000-130,000$ & & 0.85 & 6672.48 & & (21) \\
\hline As & & & & $\mathrm{CR}$ & $1.9-2000$ & & 0.05 & 195.24 & & \\
\hline $\mathrm{Cu}$ & & & & $\mathrm{CR}$ & $2.7-780$ & & 0.09 & 57.91 & & \\
\hline $\mathrm{Fe}$ & & & & SNV & $1700-85,000$ & & 0.88 & 5405.27 & & \\
\hline $\mathrm{Mn}$ & & & & $\mathrm{CR}$ & $33-3300$ & & 0.41 & 393.54 & & \\
\hline $\mathrm{Ni}$ & & & & MSC & $2.5-81$ & & 0.70 & 7.84 & & \\
\hline $\mathrm{Pb}$ & & & & SNV FD & $7.7-4200$ & & 0.00 & 438.31 & & \\
\hline $\mathrm{Zn}$ & & & & SNV & $6.8-1700$ & & 0.22 & 184.56 & & \\
\hline \multicolumn{11}{|c|}{ PXRFS } \\
\hline $\mathrm{Pb}$ & UK & 81 & & & $5-40398$ & $\begin{array}{l}\text { linear } \\
\text { regression }\end{array}$ & 0.97 & & & (63) \\
\hline $\mathrm{Cd}$ & & & & & $0-447$ & & 0.46 & & & \\
\hline As & & & & & $2.0-5646$ & & 0.87 & & & \\
\hline $\mathrm{Ni}$ & & & & & $1.0-84.0$ & & 0.34 & & & \\
\hline $\mathrm{Zn}$ & & & & & $3.0-25389$ & & 0.88 & & & \\
\hline $\mathrm{Mn}$ & & & & & $6.0-38267$ & & 0.74 & & & \\
\hline
\end{tabular}




\begin{tabular}{|c|c|c|c|c|c|c|c|}
\hline $\mathrm{Fe}$ & & & $482-91566$ & & 0.97 & & \\
\hline $\mathrm{Cu}$ & & & $3.0-5140$ & & 0.88 & & \\
\hline $\mathrm{Pb}$ & USA & 76 & $152-3590$ & $\begin{array}{l}\text { linear } \\
\text { regression }\end{array}$ & 0.98 & 4.1 & (70) \\
\hline $\mathrm{Pb}$ & Ireland & 17 & $80-30000$ & $\begin{array}{l}\text { linear } \\
\text { regression }\end{array}$ & 0.99 & & (62) \\
\hline AS & & & $<$ LOD-1230 & & 0.99 & & \\
\hline $\mathrm{Cd}$ & $\begin{array}{l}\text { South } \\
\text { Korea }\end{array}$ & 30 & & $\begin{array}{l}\text { linear } \\
\text { regression }\end{array}$ & 0.96 & & (61) \\
\hline $\mathrm{Pb}$ & & & & & 0.97 & & \\
\hline $\mathrm{Cu}$ & & & & & 0.94 & & \\
\hline $\mathrm{Zn}$ & & & & & 0.76 & & \\
\hline $\mathrm{Mn}$ & & 75 & & & 0.99 & & \\
\hline $\mathrm{Fe}$ & & 75 & & & 0.98 & & \\
\hline $\mathrm{Ni}$ & & 27 & & & 0.51 & & \\
\hline $\mathrm{Cu}$ & & 75 & & & 0.99 & & \\
\hline $\mathrm{Zn}$ & & 75 & & & 0.99 & & \\
\hline As & & 45 & & & 0.97 & & \\
\hline $\mathrm{Sr}$ & & 75 & & & 0.97 & & \\
\hline $\mathrm{Cd}$ & & 23 & & & 0.99 & & \\
\hline $\mathrm{Pb}$ & & 75 & & & 0.99 & & \\
\hline
\end{tabular}




\begin{tabular}{|c|c|c|c|c|c|c|c|c|c|}
\hline $\mathrm{Al}$ & Ireland & 322 & & $0.6-9.7$ & Cubist & 0.88 & 0.6 & 2.11 & (30) \\
\hline $\mathrm{Ba}$ & & & & $44.3-1178.9$ & & 0.90 & 40.35 & 1.66 & \\
\hline $\mathrm{Co}$ & & & & $0.7-58.7$ & & 0.80 & 2.86 & 0.84 & \\
\hline $\mathrm{Cr}$ & & & & $5.5-221.7$ & & 0.87 & 8.52 & 1.73 & \\
\hline $\mathrm{Cu}$ & & & & $1.8-104.0$ & & 0.93 & 3.77 & 1.71 & \\
\hline $\mathrm{Hg}$ & & & & $0.01-1.0$ & & 0.59 & 0.05 & 0.40 & \\
\hline $\mathrm{Mg}$ & & & & $0.1-1.5$ & & 0.61 & 0.14 & 0.71 & \\
\hline $\mathrm{Mn}$ & & & & $16.0-10287.0$ & & 0.90 & 316.41 & 0.90 & \\
\hline Mo & & & & $0.1-14.4$ & & 0.82 & 0.52 & 0.57 & \\
\hline $\mathrm{Ni}$ & & & & $1.7-176.0$ & & 0.84 & 5.84 & 1.27 & \\
\hline $\mathrm{Pb}$ & & & & $5.2-123.0$ & & 0.82 & 7.21 & 1.02 & \\
\hline $\mathrm{Cr}$ & China & 111 & Wavelet & & & 0.99 & & & (132) \\
\hline $\mathrm{Zn}$ & & & & & & 0.99 & & & \\
\hline $\mathrm{Pb}$ & & & & & & 0.99 & & & \\
\hline As & & & & & & 0.98 & & & \\
\hline $\mathrm{Zn}$ & China & 301 & & $59.0-4194$ & PLSR & 0.99 & 28.9 & 9.35 & (75) \\
\hline $\mathrm{Ni}$ & & & & $2.0-114$ & & 0.37 & 33.0 & 0.36 & \\
\hline $\mathrm{Cu}$ & & & & $8.0-297$ & & 0.95 & 12.37 & 2.88 & \\
\hline $\mathrm{Pb}$ & & & & $15.0-159$ & & 0.92 & 12.0 & 2.53 & \\
\hline
\end{tabular}




\begin{tabular}{|c|c|c|c|c|c|c|c|c|c|}
\hline As & & & & $1.0-53.0$ & & 0.73 & 6.56 & 0.92 & \multirow{4}{*}{ (133) } \\
\hline $\mathrm{Cu}$ & Italy & 294 & & $8-485$ & \multirow[t]{3}{*}{$\begin{array}{l}\text { Linear } \\
\text { regression }\end{array}$} & 0.95 & & & \\
\hline $\mathrm{Ni}$ & & & & 13-194 & & 0.93 & & & \\
\hline $\mathrm{Zn}$ & & & & $50-2477$ & & 0.97 & & & \\
\hline \multicolumn{10}{|c|}{ LIBS } \\
\hline $\mathrm{Cr}$ & Italy & 20 & & $400-700 \mathrm{~nm}$ & & & & $\begin{array}{l}\text { RSD \% } \\
1.64 \\
9.11\end{array}$ & (134) \\
\hline $\mathrm{Fe}$ & & & & & & & & 3.02 & \\
\hline $\mathrm{Mn}$ & & & & & & & & 5.56 & \\
\hline $\mathrm{Ni}$ & & & & & & & & 14.18 & \\
\hline $\mathrm{Pb}$ & & & & & & & & 5.32 & \\
\hline $\mathrm{Zn}$ & & & & & & & & 11.55 & \\
\hline $\mathrm{Cu}$ & Brazil & 59 & & & ANN & 0.96 & 0.50 & & (24) \\
\hline $\mathrm{Cr}$ & Italy & 6 & & & & 0.92 & & & (135) \\
\hline $\mathrm{Al}$ & Spain & 19 & without & & PLSR & 0.77 & 0.30 & 1.57 & (89) \\
\hline $\mathrm{Ba}$ & & & $\mathrm{FD}+\mathrm{SNV}$ & & & 0.78 & 0.90 & 1.64 & \\
\hline $\mathrm{Ca}$ & & & MMN & & & 0.80 & 0.10 & 1.66 & \\
\hline $\mathrm{Fe}$ & & & $\mathrm{FD}+\mathrm{SNV}$ & & & 0.85 & 0.02 & 1.91 & \\
\hline $\mathrm{Mg}$ & & & SNV & & & 0.92 & 0.50 & 2.63 & \\
\hline $\mathrm{Si}$ & & & SNV & & & 0.86 & 0.10 & 1.96 & \\
\hline \multirow[t]{2}{*}{$\mathrm{Cd}$} & China & 50 & Wavelet & $211.9-232.9$ & PLSR & 0.97 & 0.051 & & (94) \\
\hline & & & Wavelet & & LS-SVM & 0.98 & 0.034 & & \\
\hline
\end{tabular}




\begin{tabular}{|llllll}
\hline & & & $\left.\mathrm{LOD}_{(\mathrm{mg} \mathrm{kg}}^{-1}\right)$ \\
$\mathrm{Cu}$ & China & 25 & 0.98 & 6.28 \\
$\mathrm{Zn}$ & & 0.99 & 8.64 \\
& 0.99 & 8.55 & $(25)$ \\
\hline
\end{tabular}

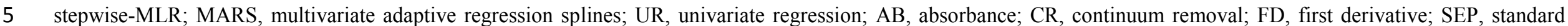

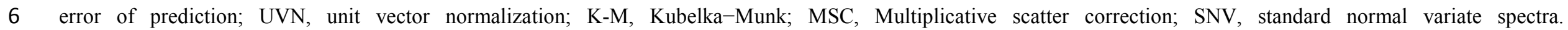


Table 2. Advantages and limitations of most common laboratory and field optical and spectroscopic techniques for determining potential toxic elements (PTEs) in soil samples.

\begin{tabular}{|c|c|c|c|c|c|c|c|c|}
\hline $\begin{array}{c}\text { Price range } \\
(1000 \$)\end{array}$ & $\begin{array}{l}\text { Targeted } \\
\text { analytes }\end{array}$ & $\begin{array}{l}\text { Sample } \\
\text { matrix }\end{array}$ & $\begin{array}{c}\text { Cost } \\
\text { per } \\
\text { sample } \\
(\$) \\
\end{array}$ & $\begin{array}{l}\text { Limit of } \\
\text { detection }\end{array}$ & $\begin{array}{c}\text { Accuracy } \\
\text { range }\end{array}$ & Advantages & Limitations & References \\
\hline \multicolumn{9}{|l|}{ PXRF } \\
\hline $25-40$ & 26 & Solid & $10-20$ & $\mathrm{mg} \mathrm{kg}^{-1}$ & $1-10 \%$ & $\begin{array}{l}\text { Fast, non- } \\
\text { destructive, } \\
\text { accuracy and } \\
\text { precision increase } \\
\text { with higher } \\
\text { element } \\
\text { concentration, } \\
\text { capable of } \\
\text { analysing a large } \\
\text { range of elements } \\
\text { from F to U, and } \\
\text { well suited for the } \\
\text { analysis of highly } \\
\text { homogeneous } \\
\text { materials. }\end{array}$ & $\begin{array}{l}\text { Sensitive to matrix } \\
\text { effect, relatively } \\
\text { expensive to run, } \\
\text { and analysis is } \\
\text { slower. }\end{array}$ & $(19,50-52,55,56,154)$ \\
\hline \multicolumn{9}{|l|}{ LIBS } \\
\hline $35-50$ & $10-15$ & Solid & $15-20$ & $\mathrm{mg} \mathrm{kg}^{-1}$ & $1-10 \%$ & $\begin{array}{l}\text { Fast, destructive, } \\
\text { accuracy and } \\
\text { precision increase } \\
\text { with higher } \\
\text { element } \\
\text { concentration, } \\
\text { capable of } \\
\text { analyzing a large } \\
\text { range of elements, } \\
\text { and well suited for }\end{array}$ & $\begin{array}{l}\text { Sensitive to matrix } \\
\text { and water content } \\
\text { effect, relatively } \\
\text { expensive to run. }\end{array}$ & $(24,77,82,89,94)$ \\
\hline
\end{tabular}




\begin{tabular}{|c|c|c|c|c|c|c|c|c|}
\hline $\begin{array}{c}\text { Price range } \\
(1000 \$)\end{array}$ & $\begin{array}{c}\text { Targeted } \\
\text { analytes }\end{array}$ & $\begin{array}{l}\text { Sample } \\
\text { matrix }\end{array}$ & $\begin{array}{c}\text { Cost } \\
\text { per } \\
\text { sample } \\
(\$)\end{array}$ & $\begin{array}{l}\text { Limit of } \\
\text { detection }\end{array}$ & $\begin{array}{c}\text { Accuracy } \\
\text { range }\end{array}$ & Advantages & Limitations & References \\
\hline & & & & & & $\begin{array}{l}\text { the analysis of } \\
\text { highly } \\
\text { homogeneous } \\
\text { materials. }\end{array}$ & & \\
\hline \multicolumn{9}{|l|}{ Vis-NIRS } \\
\hline $20-40$ & - & $\begin{array}{l}\text { All } \\
\text { matrices }\end{array}$ & $10-20$ & - & - & $\begin{array}{l}\text { Fast, non- } \\
\text { destructive, } \\
\text { potable, and } \\
\text { suitable for on-line } \\
\text { measurement, } \\
\text { accuracy and } \\
\text { precision increase } \\
\text { in more } \\
\text { homogeneous } \\
\text { materials. }\end{array}$ & $\begin{array}{l}\text { Sensitive to matrix } \\
\text { effect, needs to be } \\
\text { calibrated with } \\
\text { reference samples, } \\
\text { effects of moisture, } \\
\text { texture are moderate } \\
\text { on accuracy. }\end{array}$ & $(16,27,29,106,107)$ \\
\hline \multicolumn{9}{|l|}{ MIRS } \\
\hline $30-40$ & - & $\begin{array}{l}\text { All } \\
\text { matrices }\end{array}$ & $10-20$ & - & - & $\begin{array}{l}\text { Very fast, non- } \\
\text { destructive, } \\
\text { portable, allows in } \\
\text { situ measurement, } \\
\text { accuracy and } \\
\text { precision increase } \\
\text { in more } \\
\text { homogeneous } \\
\text { materials }\end{array}$ & $\begin{array}{l}\text { Sensitive to matrix } \\
\text { effect and soil } \\
\text { moisture, needs to } \\
\text { be calibrated with } \\
\text { reference samples, } \\
\text { and effects of } \\
\text { moisture, texture are } \\
\text { high on accuracy } \\
\text { and larger than in } \\
\text { the Vis-NIRS }\end{array}$ & $(21,30,120,143,155)$ \\
\hline
\end{tabular}

fluorescence spectroscopy; LOD = limit of detection. 